\title{
Review of surfactant-assisted chemical enhanced oil recovery for carbonate reservoirs: challenges and future perspectives
}

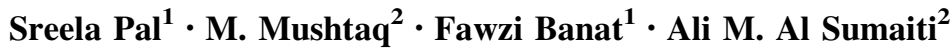

Received: 26 April 2017/Published online: 4 November 2017

(C) The Author(s) 2017. This article is an open access publication
Keywords Oil reserves - Original oil in place - Carbonate formations - Surfactants - Chemical enhanced oil recovery

\section{Introduction}

Approximately one-third of the original oil in place (OOIP) is believed to be recovered by primary and secondary recovery processes worldwide, leaving behind around $60 \%-70 \%$ as remaining oil in reservoirs ( $\mathrm{Xu}$ et al. 2017). Most of the current world oil production comes from mature fields which contain a high percentage of residual oil. Increasing oil recovery from these aging resources is the primary concern for oil companies and authorities globally. More than $50 \%$ of the world's discovered oil reserves are in carbonate reservoirs, a large number of which have a high degree of heterogeneity and complex pore structures (Masalmeh et al. 2014). According to BP Statistical Review of World Energy 2015, around $48 \%$ of the world's proved conventional oil reserves are in the Middle East (BP 2015) nearly $70 \%$ of which are in fractured carbonate reservoirs.

It is also noteworthy that more than $40 \%$ of the daily world oil production comes from these carbonate reservoirs of the Middle East which are mostly mature and contain a high percentage of residual oil (Ahmadi and Shadizadeh 2013b). Typically, the majority of the carbonate reservoirs is characterized by the presence of high-permeability fractures and low-permeability matrix. This contrast in permeability makes them challenging targets for chemical flooding. Also, some of these carbonate formations have high reservoir temperatures and contain high salinity formation brine (Lu et al. 2014b). These multiple attributes coupled with their complex wettability conditions, i.e., oil-

Edited by Yan-Hua Sun 
wet/mixed-wet surfaces, complicate reservoir characterization, production and management (Hirasaki and Zhang 2003). As a result, the oil recovery factors (ORF) in these reservoirs are very low, probably below $30 \%$ on an average (Hognesen et al. 2005).

Implementation of chemical enhanced oil recovery (cEOR) processes is highly dependent on the oil and chemical prices, and hence, research and investment in this field are decidedly governed by the economy of the country. Despite these challenges, extensive laboratory research along with some field demonstration projects support the fact that there lies an enormous potential for chemicals in enhancing oil recovery from carbonate formations. With cEOR, targeting more and more challenging reservoirs, especially using surfactants is becoming a reality (Lu et al. 2014a). During the last two decades, a considerable number of EOR field projects in carbonate reservoirs have been documented (Alvarado and Manrique 2010) of which the Yates field (Texas) is a good example where different EOR processes were successfully trialed at different levels, from pilot to large-scale applications.

Several variations to conventional surfactant flooding methods, such as the combined surfactant-polymer (SP) technologies and the alkali-surfactant-polymer (ASP) floods that boost oil production, especially in the mature water-flooded carbonate fields, have been the subject of much introspection lately (Kiani et al. 2011). Due to technical difficulties, chemical-based EOR methods have never been very popular for significantly enhanced oil production from carbonate reservoirs. Nevertheless, surfactant-based cEOR technologies have been implemented as chemical well stimulators, wettability altering agents, microemulsion, and foam-generating agents consistently (Andrianov et al. 2012; Simjoo et al. 2013; Wang and Mohanty 2013). Currently, this is an area of intense research (Ahmadi and Shadizadeh 2012; Bera et al. 2012; Zendehboudi et al. 2013; Bourbiaux et al. 2014; Santvoort and Golombok 2015).

The present review is aimed at:

(a) Studying the heterogeneity and characteristics of carbonate reservoirs,

(b) Discussing the current status of the different surfactant-based cEOR methods applied in carbonate reservoirs documenting several field EOR projects in carbonate reservoirs,

(c) Summarizing the evolution of various surfactant types for application in different carbonate reservoirs over the years and, finally,

(d) Evaluating the challenges and debating the future of surfactant EOR technology for these reservoirs.

Since carbonate reservoirs are at the leading area of research currently, this comprehensive review will undoubtedly guide future researchers and practitioners in the field toward identifying newer technologies and upgrading existing methodologies for successful field implementation.

\section{Heterogeneity and characteristics of carbonate reservoirs}

Carbonate reservoirs present a picture of extremes. Most of them are highly heterogeneous regarding their geological and petrophysical features that clearly distinguish them from sandstone reservoirs. They typically possess some distinct characteristics, which challenge oil recovery and extraction. Normally, carbonate rocks have a complex texture and pore network, emanating from their depositional history and later diagenesis. Most of the carbonate reservoirs are naturally fractured with extremes in fracture length varying from small fissures to kilometers. These fractures may significantly influence fluid movement to specific paths and hugely impact on the production performance. For example, highly fractured reservoirs can experience early water or gas breakthrough due to channeling of fluids along fractures. However, fractures are beneficial in tight formations where matrix permeability is significantly low, and most of the fluid movement is only through fractures. Therefore, characterization and understanding the behavior of fluid or gas flow through fractures is essential for a successful field development.

Most carbonate rocks are formed by biological activity, developing from the biogenic sediments gathered during reef building and accumulation of the remains of organisms on the seabed. Other types originate from evaporation of water from shallow onshore basins or as precipitates from seawater (Akbar et al. 2000). They consist of limited groups of minerals predominantly calcite and dolomite. Sometimes, minerals such as glauconite and secondary minerals including quartz, clay, pyrite, siderite, ankerite, anhydride and chert are also less commonly present (Lucia 2007).

Usually carbonate rocks are differentiated by factors such as depositional texture, grain or pore size, rock fabric or diagenesis following some classification schemes put forward by different groups of scientists (Lucia 2007; Embry and Klovan 1971). Heterogeneity may exist at all levels-in pores, grains and also in textures. The porosities of carbonate rocks are usually classified into three categories: (a) connected porosity - this porosity lies between carbonate grains (b) vugs - they are unconnected pores that arise from the dissolution of calcite by water during diagenesis and finally (c) fracture porosity-stresses cause this subsequent texture. Together these porosities create a difficult path for liquid flow and precisely affect well 
productivity. Diagenesis of carbonate rocks significantly modifies the pore spaces and permeability (Akbar et al. 2000).

Apart from porosities, wettability is another heterogeneous characteristic in carbonate rocks. Most of the carbonate reservoirs are found to be mixed-wet or oil-wet (Chilingar and Yen 1983). At times, strongly oil-wet carbonate formations leave behind a high water-flooded residual oil saturation and have unfavorable mobility ratios. Additionally, they exhibit capillary resistance to imbibition of water (Anderson 1987). Hence, oil remains adhered to the surface of the carbonate rocks, and it becomes harder to recover the entrapped residual oil. Different surfactantbased cEOR technologies targeted primarily toward carbonate reservoirs have been tried over the last two decades. In the following sections, we will discuss some of the wellpracticed surfactant-based EOR flooding methodologies.

\section{Surfactant flooding processes for chemical EOR in carbonate reservoirs}

For decades, substantial efforts have been made to use surfactant injection as a post-waterflood process for recovering entrapped oil from conventional mature reservoirs. Designing and optimizing suitable surfactant flood for effective cEOR has always been very challenging and forever evolving. It is one of the robust and high-performance cEOR methods, which has been widely studied in the past decades because of its ability to alter wettability of carbonate reservoirs from the oil/mixed-wet to the waterwet surfaces, lower interfacial tension (IFT) and produce the oil entrapped in these formations (Hill et al. 1973; Yang and Wadleigh 2000; Webb et al. 2005; Farajzadeh et al. 2010; Barnes et al. 2012; Ahmadi and Shadizadeh 2013a).

The idea of adding surfactants to injected water for reducing oil/water IFT and/or alter wettability thereby increasing oil recovery from reservoirs dates back to the early 1900s (Uren and Fahmy 1927). A similar long-held concept for improving oil recovery was the in situ generation of surfactants by injection of an alkaline solution (Howard 1927). Though this method provided a comparatively cheap in situ surfactant production technology by conversion of the naphthenic acids in crude oil to soaps, this was not immediately accepted due to poorly understood process mechanisms (Johnson 1976).

From 1960 onwards, surfactant technology advanced significantly based on two different approaches. The surfactants were either synthesized by direct sulfonation of aromatic groups present in refinery streams/crude oils or by the organic synthesis of alkyl/aryl sulfonates with the aim of manufacturing tailored surfactants for the reservoir of interest (Hirasaki et al. 2008). Similarly, use of low- concentration pure surfactants (such as ethoxylated alcohols) in injected water was also seen to improve oil recovery in oil-wet carbonate reservoirs, presumably by enhancing imbibition through wettability alteration and lowering of the interfacial tension (IFT). Such simple surfactant systems were considered viable due to low surfactant concentration requirement along with associated low adsorption (Yang and Wadleigh 2000; Xie et al. 2004; Seethepalli et al. 2004).

\subsection{Foams, wettability alteration and lowering of interfacial tension by surfactants}

Surfactants play a leading role in foam generation, wettability alteration and lowering of oil-water interfacial tension (IFT) processes.

Foams are employed for mobility control in situations where polymers, gas or water alternating gas injection schemes are not feasible due to unfavorable conditions, such as low permeability, formation heterogeneity and high temperature-high salinity conditions beyond the polymer stability window. Foam injection has advantages over simple gas injection, and it is demonstrated that the use of foam can mitigate gas channeling, improve apparent gas density and hinder gas escape through high-permeability zones to achieve good oil recovery (Julio and Emanuel 1989; Huh and Rossen 2008; Lee et al. 1991; Schramm and Wassmuth 1994). Foams are reviewed in detail in Sect. 3.4.3.

\subsubsection{Wettability alteration}

Wettability is long recognized as an important factor that strongly affects oil recovery in naturally hydrophobic carbonate reservoirs implementing cEOR methods. Wettability is defined as the preferential tendency of a fluid to spread onto a solid phase in the presence of other immiscible fluids. Generally, for an oil/water system, wettability can be defined according to the contact angle; if the contact angle is $0^{\circ}-75^{\circ}$, the rock is water wet; if $75^{\circ}-115^{\circ}$, it is intermediate and with an angle of $115^{\circ}-180^{\circ}$, the rock will be oil wet (Anderson 1986).

Wettability alteration is supremely important for naturally fractured carbonate reservoirs (NFCRs), where primary and secondary processes usually fail to mobilize oil that remains locked tightly due to capillarity. Moreover, most of the oil in NFCRs is contained in the low-permeability matrix. As the viscous forces in these heterogeneous systems are inefficient to sweep matrix oil, an imbibition process remains as the most reliable mechanism to reach for the oil.

Depending upon their hydrophilic head charges (anionic/cationic) and the charges on the rock surfaces, 
surfactants may alter the wettability of reservoir surfaces. There are two mechanisms of wettability alteration by surfactants cited in the literature (Standnes and Austad 2000b). The first is the removal of the oil-wet layer exposing the underlying originally water-wet surfaces (cationic), while the second is setting up of a water-wet layer over the oil-wet layer (anionic). For carbonates, cationic $\mathrm{C}_{12} \mathrm{TAB}$ surfactants at concentrations equal or greater than the critical micelle concentration (CMC) alter wettability better than anionic surfactants (Standnes and Austad 2000b). However, other researchers have stated that no apparent correlation exists between oil recovery and CMC (Wu et al. 2008).

From the works of Standnes and Austad (2003), it was found that ion pair interaction is a possible mechanism of wettability alteration by cationic surfactant type $\mathrm{C}_{n} \mathrm{TAB}$ (where $n$ is the number of carbon atoms). According to them, the mechanism of wettability alteration was rationally attributed to the formation of ion pairs between the cationic surfactant and the negatively charged carboxylates in oil. In addition to the electrostatic forces, hydrophobic interactions were also believed to stabilize this ion pair complex. The ion pairs were insoluble in the water phase but were found to be soluble in the oil phase or the micelles. The ion pair solubility in oil causes water to penetrate into the pore system, with the subsequent expulsion of oil from the pore through connected pores with high oil saturation in a so-called counter-current flow mode. Hence, as the adsorbed organic material released from the calcite surface, it became more water-wet.

Anionic surfactants, in general, do not possess the ability to alter the wettability of calcite surfaces, even though they can achieve a very low IFT. However, ethoxylated sulfonates with high numbers of ethylene oxide (EO) units, displaced oil spontaneously in a slow process (Standnes and Austad 2003). The proposed mechanism in this case probably involves the formation of a water-wet bilayer between the oil and the hydrophobic calcite surface. An anionic surfactant with a large hydrophobic group such as ethoxylated sulfonates of the type $\mathrm{R}-(\mathrm{EO})_{x}-\mathrm{SO}_{3}{ }^{-}(x=3-15)$ supposedly adsorbed onto the hydrophobic calcite surface forming a double layer and creating a hydrophilic surface. The water-soluble head group of the surfactant EO-group and the anionic sulfonate could decrease the contact angle below $90^{\circ}$, forming a small water layer between the oil and the organic coated surface. As a result, weak capillary forces were created, and some spontaneous imbibition of water could occur. From their experiments, Austad and Standnes showed that the fluid distribution inside the core of the $\mathrm{C}_{12-14}-(\mathrm{EO})_{15^{-}}$ $\mathrm{SO}_{3}{ }^{-}$surfactant system was non-uniform, possibly due to some inhomogeneity in wetting or core properties (Standnes and Austad 2003). However, the formation of a surfactant double layer cannot be regarded as a permanent wettability alteration of the calcite, because due to the weak hydrophobic bond between the surfactant and the hydrophobic surface, the process is entirely reversible.

Nonionic surfactants, for example, ethoxylate $\mathrm{C}_{9}-\mathrm{C}_{11}$ linear primary alcohol was also tested for its ability to change the wettability of dolomite surfaces using contact angle with Yates crude oil (Vijapurapu and Rao 2004). The advancing contact angle reduction suggested that the nonionic surfactant effectively altered the strongly oil-wet nature (advancing angle of $156^{\circ}$ ) to the water-wet state (advancing angle of $39^{\circ}$ ).

\subsubsection{Interfacial tension}

Interfacial tension (IFT) is one of the primary considerations in alkali-surfactant flooding cEOR processes. In oil reservoirs, the interplay of three types of forces, capillary, gravitational and viscous forces, controls the extent and rate of oil recovery. To best describe the relationship between these forces, there are two useful numbers-the Bond number $\left(N_{\mathrm{B}}\right.$, which presents the ratio of gravitational forces to capillary forces) and capillary number $\left(N_{\mathrm{c}}\right.$, which presents the ratio of viscous forces to capillary forces) as outlined below:

$N_{\mathrm{B}}=\frac{\text { Gravitational forces }}{\text { Capillary force }}$

$N_{\mathrm{c}}=\frac{\text { Viscous forces }}{\text { Capillary forces }}$

Capillary forces $\quad F_{\mathrm{c}}=\frac{2 \sigma_{\mathrm{ow}} \cos \theta_{\mathrm{c}}}{r}$

Gravitional forces $\quad F_{\mathrm{G}}=\Delta \rho g h$

where $\sigma_{\text {ow }}$ is the oil-water interfacial tension, $\mathrm{N} / \mathrm{m} ; r$ is the pore radius; and $\theta_{\mathrm{c}}$ is the contact angle.

The denominator in both of these numbers is the capillary force, which is a function of the IFT between oil and water, surface wettability represented by the contact angle $\left(\theta_{\mathrm{c}}\right)$ and the pore radius $(r)$. Viscous forces cannot be applied efficiently for heterogeneous oil-wet NFCRs due to a high-pore-volume matrix which possesses low permeability and a much lower volume fracture system that controls the flow of viscous displacement. Fluid dynamics in this type of reservoir is controlled by the Bond number $\left(N_{\mathrm{B}}\right)$. Depending upon the contact angle $\left(\theta_{\mathrm{c}}\right)$ (wettability of rock), the value of the capillary forces may be reversed from negative to positive figures. For oil-wet cores, the contact angle of water with rock being greater than $115^{\circ}$, no capillary imbibition takes place. According to Morrow and Mason, the ratio of gravitational forces to capillary force is significantly important and lowering of IFT may positively or negatively affect imbibition (Morrow and 
Mason 2001). Even when lowering of IFT reduces capillary imbibition, imbibition may occur due to the gravitational forces. Capillary imbibition can be initiated and maintained as long as the IFT is not reduced below certain critical values. The interplay between gravitational and capillary forces greatly depends on the IFT value.

For oil-wet carbonate systems, the capillary pressure is usually negative, and as a result, water does not imbibe spontaneously into the porous medium as oil is firmly attached to the rock surface by capillarity. By reducing the IFT by the use of surfactants, the adhesive forces that retain oil by capillarity are weakened. Due to lowering of IFT, capillary trapping is reduced, and this causes oil droplets to flow more smoothly through pore throats and merge with oil down the stream to form an oil bank (Sheng 2015). Lowering of IFT between oil and brine and combination of specific conditions of temperature and salinity lead to the generation of microemulsions. Microemulsions play a vital role in chemical EOR and are reviewed in next section.

Recent spontaneous imbibition studies by Mohammed and Babadagli, for two limestone core samples exposed to two different aqueous phases, distilled water, and 1.0wt $\%$ of cationic surfactant $\mathrm{C}_{12} \mathrm{TAB}$ came up with some notable results (Mohammed and Babadagli 2014). The spontaneous imbibition curve indicated the oil-wet nature of the core samples and the negative capillary forces resisted the gravitational forces when the core samples were exposed to distilled water. A similar trend was observed for a core sample exposed to the surfactant solution initially (for 10 days), indicating slow recovery. Nevertheless, after 10 days, a sudden hike in recovery was observed, which was possibly due to the wettability alteration by surfactant that enhanced capillary imbibition. Cationic surfactants function to change wettability to the extent that it induces capillary spontaneous imbibition (Standnes and Austad 2000b). On the other hand, alkaline anionic surfactants reduce the negative capillary forces significantly. Some anionic surfactants can lower IFT to ultra-low values where the capillary pressure is nearly zero. From the simulation results of a dynamic imbibition process study, it was found that the transverse pressure gradients between the fracture and matrix at times pushed the surfactant further into the matrix (Asl et al. 2010). Hence, gravitational forces became active, and oil was recovered by gravity-induced imbibition (Hirasaki and Zhang 2003).

\subsection{Microemulsion phase behavior of surfactants}

Microemulsions are thermodynamically stable, homogeneous dispersions of two immiscible fluids, generally, hydrocarbons and water stabilized with surfactant molecules, either alone or mixed with a co-surfactant (Schwuger et al. 1995). They possess the ability to reduce IFT between oil and water to an ultra-low value and also can alter the wettability of reservoir rocks (Zhu et al. 2003). The principal constituents of microemulsions are the surfactants adsorbed at the interphase rather than in the bulk phase. The IFT values between microemulsion and crude oil; and between microemulsion and water are very low, typically in the range of $10^{-3} \mathrm{mN} / \mathrm{m}$.

The IFT behavior of microemulsions is best described by examining the phase behavior of the surfactants/cosurfactant-brine-oil system. IFT behavior is believed to be a key factor in predicting the performance of oil recovery

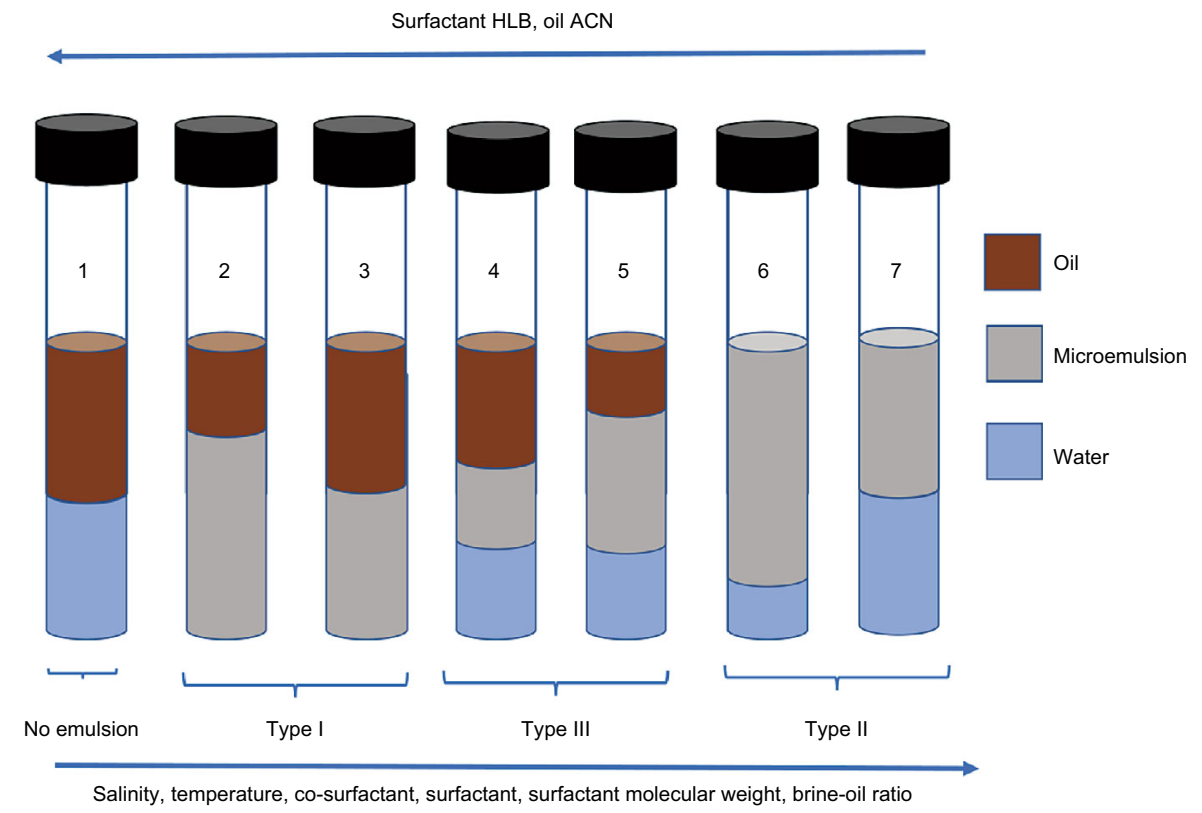

Fig. 1 Microemulsion phase behavior of surfactants-water-oil as a function of different variables 
by the microemulsion flooding process (Kayali et al. 2010). Essential concepts and details on the phase behavior of microemulsion systems have been presented by Winsor and later, others (Winsor 1956; Schwuger et al. 1995). Depending on the surfactant type, the microemulsion phase behavior changes from Winsor I (lower phase) to Winsor III (middle phase) to Winsor II (upper phase) by varying the following conditions: (1) salinity increase, (2) alcohol (co-surfactant) concentration increase, (3) surfactant molecular weight increase, (4) oil chain length (alkane carbon number, ACN) decrease, (5) temperature change, (6) total surfactant concentration increase, (7) surfactant solution/oil ratio increase, (8) surfactant hydrophile-lipophile balance (HLB) decrease, (9) brine/oil ratio increase, as depicted in Fig. 1 (Salager et al. 2005).

\subsubsection{Effect of surfactant structure on IFT behavior}

Achieving ultra-low IFT is essential for mobilizing the residual oil in reservoir rocks and reducing the oil saturation toward zero under normal pressure gradients in oil reservoirs. Surfactants with large hydrophobes are not salinity tolerant. However, the addition of large ethylene oxide and propylene oxide groups may help to achieve required salinity tolerance. These surfactants with bulky hydrocarbon chains may form high solubilization ratios when compared to similar counterparts with relatively shorter hydrocarbon chains in their structures. In general, when all other parameters are constant, the longer the hydrocarbon tail in the surfactant structure, the lower will be the optimum salinity.

To transport surfactant solutions under low pressure gradients, a condition typical in carbonate reservoirs, highly viscous phases must be avoided, because they result in high surfactant retention and ultimately poor recovery. Using surfactants with branched hydrophobes could be a possible solution for abating this problem of viscosity. Likewise, the addition of propylene oxide (PO) and ethylene oxide (EO) units to sulfate surfactant molecules helps in increasing solubilization of the microemulsion phase with a broader region of low IFT due to the interphase affinity of the groups. Improved calcium tolerance is an additional benefit (Salager et al. 2005). From the studies of Hussain et al. (1997), it was found that the presence of an EO moiety in the surfactant molecule made the surfactant less sensitive to salinity than an anionic surfactant. Salinity and surfactant concentration influence the surfactant retention in reservoir rocks. Surfactant adsorption is possibly one of the most restrictive factors that affect the oil recovery efficiency by microemulsion flooding (Glover et al. 1979; Hussain et al. 1997) and will be reviewed in detail shortly. The carboxylic ionic head group-containing surfactants are more stable to temperature changes than pure EO nonionic surfactants. Increasing the number of EO units in a surfactant molecule makes it more hydrophilic; hence, it can withstand high salinity and temperature to achieve its optimum functionality, a character highly desirable for high-temperature high-salinity carbonate reservoirs (Hussain et al. 1997). On the other hand, the addition of PO units will add mild hydrophobic character, which can help achieving high solubilization of oil and brine phases.

\subsubsection{Effect of salinity and temperature on IFT behavior}

Salinity has a strong influence over different microemulsion structures, which in turn affects the carbonate rock wettability behavior. From the studies of Dantas et al. (2014), it is noticed that with an increase in salinity, there is a decrease in wettability inversion from oil-wet/mixedwet to water-wet surfaces. However, due to the continuous oil phase of reverse microemulsions, they exhibit favorable interactions between the oil phase and the oil contained in carbonate rocks with better wettability results, reducing the IFT and consequently enhancing oil displacement from the rock pores. For bicontinuous microemulsions, an increase in salinity (within an acceptable range for bicontinuous emulsion phases) improved the limestone rock wettability on water for anionic (SDS) and nonionic (UNT90) surfactants and increased wettability for cationic (cetyl trimethyl ammonium bromide, CTAB) surfactants. The wettability alteration to water-wet conditions influenced the oil recovery efficiency in the order of CTAB $>$ SD$\mathrm{S} \approx$ UNT90 facilitating the oil displacement.

The temperature of a reservoir is a significant parameter when surfactant performance is evaluated. A high-temperature, high-salinity reservoir presents severe challenges regarding surfactant compatibility and stability in brine. However, surfactant adsorption may decrease at high temperature conditions for highly soluble surfactants, and, on the other hand, poor solubility may lead to high adsorption values. Typically, the surfactants working at higher temperature systems show high optimum salinity (Shah 1981). As longer surfactant hydrophobes require low optimum salinity at a particular temperature, usually a heavy hydrocarbon surfactant is needed for high temperature conditions and relatively low salinity situations. However, there are some exceptions also reported, where surfactants (long chain IOS) show low optimum salinity at high temperature conditions (Barnes et al. 2008).

When all the other parameters are kept constant, under a low water content, the microemulsion system is oil-external (reversed), while under a high water content, the system is water-external (direct). As the mature carbonate reservoirs of the Middle East are mostly water-flooded, the microemulsions designed for them are a water external 
system (Winsor Type I) with oil solubilized in the core of the micelles. However, as salinity plays a significant role in reversing the structure of the microemulsion, with an increase in salinity, the direct microemulsion structure changes to reverse microemulsion (water dispersed in oil) system (Sheng 2010). At lower temperature, the viscosity of the microemulsion system increases with increasing water content, creating swollen micelles or other undesired structures. The magnitude of this viscosity change of the microemulsion system (displacing fluid) relative to the oil (displaced fluid) may become important design variables that affect the volumetric displacement efficiency, affecting the overall oil recovery efficiencies (Bera and Mandal 2015). However, in general terms, microemulsions or emulsions are scarcely designed and used for viscositybased applications in reservoirs. The primary reason is the adverse effects of viscous phases, such as high surfactant retention, high IFT, fragile structure and plugging tendencies under certain conditions.

\subsubsection{Co-surfactants}

The co-surfactants used in microemulsions are alkanols, which are medium chain alcohols such as propanol, butanol, isoamyl alcohol, pentanol, hexanol and so forth (Barakat et al. 1983). It is considered that these co-solvents have well-documented roles in microemulsion-based EOR applications (Pattarino et al. 2000; Zhou and Rhue 2000). Some of the functions include:

(a) Preventing the formation of gel-like or polymer-rich phases, which may separate out from the surfactant solution. The alcohol used in these formulations act as a co-solvent and partitions itself among the bulk oil and brine phases making the films less rigid and thereby preventing the formation of undesirable viscous phases and emulsions (Sahni et al. 2010).

(b) Alteration of the viscosity of the system,

(c) Increasing the mobility of the hydrocarbon tail, thereby allowing for greater penetration of the oil into the region.

(d) Modification of the hydrophilic-lipophilic balance (HLB) values of the surfactants. However, a significant disadvantage of using an alcohol co-solvent lies in the fact that it decreases solubilization of oil and water in microemulsions, increasing the minimum value of achievable IFT for a given surfactant.

\subsection{Surfactant adsorption process on carbonates and its mitigation and management}

In challenging conditions of carbonate reservoirs, highperformance surfactants are required which, in most of the cases, are expensive chemicals. During chemical flooding process, surfactant loss is common which inevitably reduces the surfactant availability to mobilize trapped oil. Different processes act simultaneously for this loss. One of the main processes is surfactant adsorption onto the surface of the rock. Other processes include precipitation of surfactants and phase trapping.

Surfactant adsorption and loss have been studied extensively (Ahmadall et al. 1993; Lv et al. 2011; Somasundaran and Zhang 2006). Due to high surfactant costs, surfactant adsorption is considered as one of the key processes which define the overall chemical EOR performance and its economic feasibility by determining the total amount of surfactant required for the EOR process (Lefebvre et al. 2012; Tay et al. 2015). Many factors may affect the adsorption process such as oil saturation, rock mineralogy, especially clay contents, reservoir temperature, the salinity of formation water, divalent cations, ion exchange process and surfactant structure. When the surfactant adsorption control is considered, almost all other parameters are controlled by reservoir conditions, and only the surfactant structure is the available option to control with salinity of reservoir when using the salinity gradient technique, which will be discussed shortly.

Phase trapping, on the other hand, is the migration of surfactants to the oil phase or in the microemulsion phase. The surfactant may transfer to the oil phase due to high temperature, high salinity, and high-divalent ions. Combine effect of these conditions may lead to surfactant loss, and ultra-low IFT conditions cannot be met.

Surfactant adsorption may follow several mechanisms. Zhang and Somasundaran (2006) discussed several mechanisms for surfactant adsorption. Important are electrostatic interactions between the surfactant and the solid surface. These interactions are between the charged head (positive in cationic; and negative in anionic surfactants) and the rock surface. In addition to those, the lateral interactions of hydrocarbon chains are also involved in surfactant adsorption after the first phase of surfactant head-rock surface adsorption is accomplished. Another important mechanism is the reduction of the solubility of surfactants in the aqueous phase due to an increase in salinity or temperature.

With an understanding of the mechanism of surfactant adsorption, several strategies were proposed and tried for surfactant adsorption control. These include the use of cationic surfactants, alkali, salinity gradient and adsorption inhibitors.

As electrostatic interactions play a leading role in surfactant adsorption (Somasundaran and Hanna 1977), it is suggested in the literature that cationic surfactant adsorption is less compared to anionic surfactants (Ahmadall et al. 1993). However, Ma et al. (2013) reported that the 
adsorption of cationic surfactants might lead to significantly high levels when the rock contains other minerals as well. They reported a stronger adsorption of hexadecyl pyridinium chloride on natural carbonates (containing silicon and aluminum) than on synthetic carbonates (highly pure calcite). In their study, they found sodium dodecyl sulfate (SDS) was adsorbed comparatively less than hexadecyl pyridinium chloride on carbonate surfaces. Similarly, Rosen and Li explained the adsorption of double chain (Gemini) surfactants and conventional single chain surfactants on limestones (Rosen and Li 2001). The adsorption of Gemini surfactants was high, despite having a similar charge on the head group. They attributed this strong adsorption to the relatively high bulk of the carbon chain and hydrophobic interaction between the chains. In addition to that, they reported that molar absorption of anionic surfactants was relatively lower than for cationic surfactants (Rosen and Li 2001). These reports suggest that cationic surfactants are not the only solution to the problem of high surfactant adsorption on carbonates. Moreover, the adsorption on the carbonate surface is highly dependent on the salinity and the presence of impurities on the surface of the rock.

In another proposed approach, a salinity gradient is suggested by Hirasaki et al. (1983). In this method, a slug of surfactant (S, SP or ASP) is injected and then followed by low salinity brine injection. Therefore, high salinity formation brine is first replaced by optimum salinity brine, and then, optimum salinity brine is replaced by low salinity brine. In the start of injection, a Type II microemulsion phase is generated which eventually changed to optimum Type III phase microemulsion due to the attaining of low salinity conditions. In the last stage, low salinity brings the Type I microemulsion. It is suggested that both Type II and Type III show high retention while the following Type I shows low adsorption thus completing the process. The associated problems with this approach are the possibility of inappropriate mixing of brines in the reservoir, availability of low-salinity brine in the field and logistic issues. It is also important to note that the salinity gradient effect has not been studied in carbonate rocks (Tay et al. 2015).

More recently, adsorption inhibitors and sacrificial agents are also proposed by many researchers to mitigate the adsorption problems (Tabary et al. 2012; ShamsiJazeyi et al. 2014a, b; Delamaide et al. 2015; He et al. 2015; Tay et al. 2015). These are chemicals which preferentially adsorb on the surface thereby reducing the chances of adsorption of expensive surfactants. In recent studies, it is reported that polyelectrolytes such as polystyrene sulfonate and polyacrylate may preferentially bind the available sites on the rock surface and reduce surfactant adsorption significantly. ShamsiJazeyi et al. reported that sodium polyacrylate successfully reduced the adsorption of anionic surfactants on carbonate and clay minerals while it was not effective on sandstones (ShamsiJazeyi et al. 2014a, b). In another study, calcium lignosulfonate was evaluated for its adsorption properties on limestones (Bai and Grigg 2005). It was reported that calcium lignosulfonate followed pseudo-second-order kinetics and its adsorption increased with the salinity increase. Moreover, the desorption process was slow which makes it an excellent sacrificial agent to reduce surfactant adsorption.

\subsection{Surfactant flooding}

Historically, as well as in present-day research, the primary focus of surfactant use in EOR is their microemulsionproducing ability with crude oil in the presence of brine and generating stable foams with gas. Recently, however, their capabilities of wettability alteration have also been given much focus in EOR research.

As the microemulsion proceeds in the reservoir, it collects oil, forming an oil bank during the process. This oil bank then pushed to the production well by using polymer drive. Foams, on the other hand, are used as mobility control agents when polymers fail due to salinity, temperature or permeability limitations.

\subsubsection{Alkali-surfactant flooding}

The concept of combined injection of alkali and surfactants was once thought to be one of the most promising flooding methods for enhanced oil recovery. Low-cost alkaline agents, such as sodium hydroxide and sodium carbonate, were being used together with many kinds of surfactants to enhance the oil recovery efficiency. In an alkali-surfactant process, the primary role of the alkali is to reduce adsorption of surfactant on the rock surface sequestering divalent ions. Additionally, alkali injection also generates in situ surfactants from the naphthenic acids of crude oil (Johnson 1976). However, application of alkali is not free of problems and challenges such as scaling and production of highly stable emulsions (Zhu et al. 2012).

Early work on surfactant-alkali flooding was documented in the literature (Mayer et al. 1983; McCafferty and McClafin 1992; Falls et al. 1994). However, this cEOR technique was mostly carried out in sandstone reservoirs for producing medium and light oils (Wang et al. 2010). From the review of Alvarado and Manrique 2010, it was seen that out of the 1507 international EOR projects; most applications were in sandstone reservoirs. The recovery factor of this process was mostly small, especially for fractured carbonate formations, probably due to unfavorable mobility ratios.

Four proposed mechanisms of alkaline flooding for enhanced oil recovery were summarized by Johnsen and 
later by Sheng 2013. These are emulsification-entrainment, emulsification-entrapment, wettability reversal, and emulsification-coalescence, of which emulsification is possibly the most important mechanism (Sheng 2011, 2013). Different types of emulsions are formed when residual oil comes into contact with the alkaline flooding fluid under different reservoir conditions (Bai et al. 2014). When low viscosity direct $(\mathrm{O} / \mathrm{W})$ emulsion is formed, it can quickly flood out through pore throats, consequently enhancing the displacement efficiency, as observed in the works of Jennings et al. (1974). A possible explanation for this observation could be that the direct $(\mathrm{O} / \mathrm{W})$ emulsions dampened viscous fingering and improved sweep efficiencies. Similar observation was also reported in the works of Symonds et al., where depending upon the concentration of the $\mathrm{NaOH}$ solution, two different mechanisms (emulsificationentrainment and emulsification-entrapment) for improved oil recovery was noticed (Symonds et al. 1991).

As stated earlier, surfactant plays a pivotal role in microemulsion formation, and among all surfactants, anionic surfactants are the most well-known and widely used surfactants in oil recovery (Liu et al. 2008). The domain of cationic surfactant-based microemulsion methods is still less explored, and this could be a future area of research for scientists targeting enhanced oil recovery from carbonate reservoirs. There are few literature reports available on the application of cationic surfactant-based microemulsions in EOR. In a study, Zhu et al. 2009, reported the use of a mixture of Triton X 100 (nonionic) and cetyl trimethyl ammonium bromide (CTAB) (cationic) microemulsion in lowering IFT between crude oil and the aqueous phase (brine) for additional oil recovery. Recent investigations show that cationic surfactants, for example CTAB, perform better than anionic surfactants in wettability alteration of carbonate rocks to more water wet (Saleh et al. 2008).

Again, when the reverse (W/O) emulsions are formed, due to their high viscosity, they block the water channels and pore throats in the process of migration (Kang et al. 2011). This phenomenon is particularly relevant for heavy oil recovery as observed in the works of Pei et al. (2011), and later, by Dong et al. (2012). A bank of viscous (W/O) emulsion forms when an acidic heavy oil is displaced by an alkaline solution prepared in a high-salinity brine in a porous medium. This emulsion plugs the growing water fingers and channels and diverts the flow to an initially unswept area resulting in a dramatic rise in the corresponding sweep efficiency (Ge et al. 2012).

\subsubsection{Alkali-surfactant-polymer flooding}

Adding a polymer to the surfactant solution or alkali-surfactant solution improves its sweep efficiency. This approach came to be known as "alkali-surfactant-polymer" (ASP) flooding or surfactant-polymer flooding (SP) depending on the contents of the injection slug. From its initiation, the ASP method has been identified as a costeffective cEOR process, yielding high recovery rate, mostly for sandstones and to a limited extent for carbonate reservoirs (Olajire 2014). ASP for carbonate reservoirs received little focus until the last few years. Reasons include: the high-divalent-ion environment of the carbonate reservoirs leads to the formation of calcium and magnesium sulfonates with the typical commercially available surfactants (alkyl/aryl sulfonates) that either precipitate or partition out into the oil phase (Liu et al. 2008). An exception to this observation was reported in the early works of Adams and Schievelbein 1987, who demonstrated that oil could be displaced from a carbonate reservoir using a mixture of petroleum sulfonates and alkyl ether sulfates or alkyl/aryl ether sulfates.

Use of cationic surfactants for promoting desorption of acids from carbonate rock surfaces and making the rock more water-wet was proposed by Standnes and Austad (2003). Similarly, other researchers of the time (Xie et al. 2004; Chen et al. 2000) investigated the effectiveness of various other surfactants in altering wettability. Their studies suggested that ASP solutions could be injected into carbonate formations to increase oil recovery. Related experimental approaches and simulations of the performance of ASP under field conditions were pursued (Seethepalli et al. 2004; Adibhatia et al. 2005). Of late, other studies reported combination flooding using polymers and surfactants for high-temperature, high-salinity carbonate reservoirs of Indonesia $\mathrm{KS}$ oilfields (Zhu et al. 2013). They used two competent polymers, namely STARPAM and KYPAM with suitable viscosifying abilities along with two surfactants, AS-13 (amphoteric) and SPS1708 (anionic-nonionic) for a weak alkaline ASP system. These systems could reduce the IFT to ultra-low levels $\left(10^{-3} \mathrm{mN} / \mathrm{m}\right)$ within a wide range of alkalinity $\left(0.2 \mathrm{wt} \%-1.0 \mathrm{wt} \% \mathrm{Na}_{2} \mathrm{CO}_{3}\right)$. The addition of sodium carbonate as an alkali markedly reduced the adsorption of anionic surfactants over the calcite and dolomite surfaces, diminishing one of the very typical problems of surfactant adsorption and thus making the process applicable for carbonate formations (Hirasaki and Zhang 2003). They also confirmed that carbonate precipitates did not affect permeability to a great extent, which was discussed in a previous study by Cheng (1986). In addition to that, carbonate/bicarbonate ions are potential determining ions on carbonate rocks and can shift the zeta potential to a more negative value. More negative zeta potential can influence the water wetness of rock which promotes oil displacement. Furthermore, alkalis injected in ASP processes also generate soap in situ by reaction between the alkali and 
naphthenic acids in the crude oil, which forms an oil-rich colloidal dispersion as mentioned earlier (Johnson 1976). The local ratio of this soap/surfactant determines the optimal salinity for minimum IFT (Hirasaki et al. 2008). Core flooding experiments revealed that more than $17 \%$ $18 \%$ additional oil recovery over water flooding could be obtained with either ASP or SP flooding in carbonate reservoirs. ASP processes utilized the benefits of three flooding methods, whereby oil recovery was significantly enhanced, by decreasing IFT, increasing the capillary number, enhancing microscopic displacing efficiency and improving mobility ratio (Shen et al. 2009). However, despite these advantages, the success of the ASP projects was not without certain limitations. Problems of severe scaling in the injection lines with strong emulsification of the produced fluid significantly impeded the implementation of ASP flooding technologies (Gao and Towler 2011; Wang et al. 2009). Also, polymers could not be efficiently used under high salinity conditions, because high salt conditions degraded their viscosity. Moreover, multicomponent formulations always run the risk of chromatographic separations in the reservoir, as demonstrated in the ASP project in the Daqing Oilfield in China ( $\mathrm{Li}$ et al. 2009). Improving the status of these commercially available viscosifiers by the incorporation of salt tolerant monomers, so that cheap alkalis such as sodium carbonate are successfully used, and employing associative mechanisms that allow for lower molecular weight polymers with improved injectivity are still under way.

\subsubsection{Surfactant foams}

Currently, surfactant-aided $\mathrm{CO}_{2}$ flooding is being tested in Middle East carbonate reservoirs (Al-Mutairi and Kokal 2011). Owing to its physical properties and established multiple interactions with oil over a wide range of pressures and temperatures, $\mathrm{CO}_{2}$ is considered to be one of the most important displacing fluids in gas-based EOR technology (Blunt et al. 1993; Mathiassen 2003). However, there are several problems associated with the gas injection (Sagir et al. 2013). Among them, the greatest challenge with $\mathrm{CO}_{2}$ gas injection lays in its poor volumetric sweep efficiency owing to its low density and viscosity. Lighter gas overrides gravity and a large portion of recoverable oil in the lower permeability regions cannot be contacted. This poor sweep leaves behind an extensive amount of oil in the reservoir. Though the microscopic sweep efficiency of $\mathrm{CO}_{2}$ is quite high, its viscosity $(\sim 0.01 \mathrm{cP})$ is much lower than both water $(\sim 1.0 \mathrm{cP})$ and most of the crude oils (0.6-10 cP for conventional oils) which leads to many conformance and mobility concerns and instability in the displacement front. Problems of poor volumetric sweep efficiency, gas channeling through high-permeability streaks, and gravity override are frequent (Hanssen et al. 1994). One of the strategies to meet these challenges is to utilize foam, a dispersion of gas in a continuous liquid that lowers the mobility ratio. Boud and Holbrook (1958) demonstrated for the first time that foam could be generated in an oil reservoir by sequential injection of aqueous surfactant solution and both miscible and immiscible gas drives to increase its sweep efficiency. However, due to lack of proper understanding of the mobility control mechanism by foam, the concept was not adopted widely (Li et al. 2010). Nevertheless, as the understanding of foam mobility control advanced, there have been many field tests of foam application since then. One of the most successful field pilot tests of foam mobility control in the Snorre field is a well-known example (Blaker et al. 1999). Le et al. (2008) performed a successful series of experiments on carbonate rocks to study the injection strategy for foam generation and emphasized the potential of foam as a mobility control agent (Le et al 2008).

Mobil's Slaughter and Greater Aneth field trials (1991-1994) were initial successful attempts of foam utilization for enhanced oil recovery. In this case, out of the four $\mathrm{CO}_{2}$-foam field trials, two were performed at the Greater Aneth field in carbonate reserves (South Utah). The outcome of all of these trials highlighted a sharp decrease in $\mathrm{CO}_{2}$ injectivity and a significant increase in oil production.

Earlier, foam injection strategies such as water alternating with gas (WAG) were considered as the technology of choice for controlling $\mathrm{CO}_{2}$ gas mobility (Enick et al. 2012). However, even then, complications, for example, viscous instabilities and gravity segregation, especially for heterogeneous reservoirs could not be defeated (Rogers and Grigg 2001). As a possible solution to these complications, foam-assisted EOR, such as the alkali-surfactant-gas (ASG) process, is one of the newly introduced successful synergistic combination of chemical and gas EOR methods, especially for carbonate reservoirs ( $\mathrm{Li}$ et al. 2010; Srivastava et al. 2009). The ASG process exhibits lower mobility in high-permeability layers and hence understandably blocks or hinders the flow in these layers. Simultaneously, the flow in low-permeability layers is reasonably favored with enhancing oil recovery (Farajzadeh et al. 2012). Since ASG processes combine both the concepts of IFT lowering and using foam as mobility control agents, they are mostly encouraged for HTHS carbonate reservoirs, where the functioning of polymers usually deteriorates (Lake 1989; Niu et al. 2001). In recent experimental studies as reported in the works of Nguyen, 2010, a twin-tailed dioctylglycerine surfactant showed excellent performance in significantly reducing mobility and recovering oil remarkably from a carbonate rock core flood experiment. Based on these experimental findings, it 
is summarized that ASG foams affect the oil recoveries in three ways when compared to gas or WAG flooding (Andrianov et al 2012; Farajzadeh et al. 2010):

(a) By increasing the viscosity of the displacing fluid (gas or foam), the displacement process is stabilized;

(b) By blocking the high-permeability swept layers and diverting the fluids into low-permeability unswept zones; and

(c) By reducing the IFT with its present surfactants, reducing the overall capillary force.

One of the major concerns that subdue the application of foam as an EOR method is its stability (longevity) concerns when in contact with crude oil. Many experiments performed to interpret foam stability in bulk, and porous media have demonstrated the detrimental effect of oil on foam stability (Andrianov et al. 2012; Farajzadeh et al. 2010; Vikingstad and Aarra 2009; Vikingstad et al. 2005). In many cases, the oil saturation must become low enough, before the gas mobility can be reduced by foams. Usually, two mechanisms of interaction between foam films and oil phase might occur when they come in contact with each other. Either the oil phase might probe into the foam film and destabilize it, or the foam film might slide over the water phase covering the oil. The first possibility is most common and expected, while the latter case if raised will generate a new oil/water interphase-a "pseudo-emulsion or asymmetric" film. Studies of these asymmetric films are supremely important in predicting and controlling the stability of foam in the presence of oil. However, reports on the pseudo-emulsion are very rare (Jones et al. 2016).

Sometimes, traditional commercial nonionic or anionic surfactants used in $\mathrm{CO}_{2}$ foam-based recovery are unsuitable for application in the HTHS reserves. The cloud points of ethoxylated nonionic surfactants are consistently way below $100{ }^{\circ} \mathrm{C}$ (Adkins et al. 2010), and the solubility of most nonionic surfactants decreases in brine as the salinity increases (Rosen and Kunjappu 2012). There are reports of several laboratory scale tests and field trials using anionic sulfate and sulfonate surfactants for high-salinity limestone reservoirs (Hirasaki et al. 2008; Levitt et al. 2006). However, due to the electrostatic force of attraction, they often adsorb strongly on the positively charged limestone surfaces in the presence of dissolved acidic $\mathrm{CO}_{2}$ at high pressures (Lawson 1978, Wang et al. 2015). Cationic surfactants, on the other hand, exhibit low adsorption on carbonate formations, due to the electrostatic repulsion between the cationic head and the positive charge bearing carbonate surface (Hirasaki et al. 2008; Ahmadall et al. 1993; Lawson 1978). Nevertheless, they are rarely soluble in $\mathrm{CO}_{2}$, although there are reports of a few exceptions (Smith et al. 2007).
To overcome these limitations, ethoxylated nonionic to cationic switchable amine surfactants were designed and introduced in a series of sand pack experiments (Chen et al. 2012, 2014). Ethoxylated amines are switchable from being nonionic in brine to cationic in the presence of an acidic aqueous phase such as $\mathrm{CO}_{2}$ (Elhag et al. 2014a). Reactions between primary, secondary or tertiary amines with an appropriate alkoxylation agent generated these ethoxylated amines. Relative to the size of a hydrophobic chain of alkyl amines, the size of the hydrophilic group increased with ethoxylation, which in turn increased the hydrophilicity (Chen et al. 2014). Because of the proper balance in the number of carbons in their alkyl chains and the number of ethylene oxide (EO) groups attached to the tertiary nitrogen in their head groups, ethoxylated alkyl amines of the form $\mathrm{C}_{12-14} \mathrm{~N}(\mathrm{EO})_{x}$ were found to satisfy several essential requirements for effective $\mathrm{CO}_{2}$-EOR. This surfactant was highly soluble in the $\mathrm{CO}_{2}$ phase because the nitrogen atom remained unprotonated in this phase. While in a low-pH aqueous phase due to dissolved $\mathrm{CO}_{2}$, the positively charged protonated amine rendered the surfactants more hydrophilic and raised the cloud point to $120{ }^{\circ} \mathrm{C}$. Further, in the presence of $\mathrm{CO}_{2}$, the adsorption of ethoxylated alkyl amines (dissolved in brine) on limestone surfaces was significantly reduced due to the positively charged cationic head group. Thus, switchable ethoxylated amine surfactants can be considered as a new generation surfactant, which uniquely combine the high cloud point of ionic surfactants in water with high solubility in $\mathrm{CO}_{2}$ for nonionic surfactants, stabilizing foam formations at $120^{\circ} \mathrm{C}$ with minimal adsorption on limestone (Elhag et al. 2014b). Nonetheless, switchable surfactant experiments are still in the primary stage, and much in-depth exploration needs to be done for proper understanding and acceptance of this cEOR technique in actual field applications. Some possible problems may be the maintenance of a low enough $\mathrm{pH}$ to keep them protonated and in a dissolved state in brine. There is the possibility of dissolving or corroding carbonate formation in low $\mathrm{pH}$ conditions.

\subsubsection{Biosurfactants from bacteria and renewable resources}

To improve the cost effectivity of surfactant flooding, many researchers have investigated oil displacement by biosurfactants primarily produced from bacteria during the past decade (Banat 1995; Youssef et al. 2007; Joshi et al. 2008; Al-Sulaimani et al. 2010). Biosurfactants are claimed to be eco-friendly, non-toxic and biodegradable compared to synthetic and toxic chemicals that are dangerous for oil workers and the environment. The economy of the commercial production of these materials is affected by the downstream processing costs which are about $60 \%$ of the 
total production cost of many biological products. Nevertheless, studies indicate that crude or impure biosurfactants obtained at the initial stage of recovery can be efficiently used for oil recovery applications (Ghojavand et al. 2012).

Efficient biosurfactants could be produced from inexpensive and renewable sources such as sugar cane molasses with a cost of lower than $0.5 \$$ per liter (Oscar et al. 2007). Green, environment-friendly, non-toxic surfactants such as $0.5 \%$ alkyl polyglycoside (APG) derived from a sugar source in a binary system with $0.5 \% \mathrm{NaHCO}_{3}$ reduced the IFT, improved interface wettability, exhibited compatibility with injected and produced water and demonstrated low adsorption on calcite plates derived from the G Oilfield in Kuwait (Yin and Zhang 2013). Results obtained from a recent experimental study by Ghojavand et al. showed that a lipopeptide biosurfactant produced by Bacillus mojavensis PTCC 1696, isolated from an Iranian oilfield, could appreciably reduce the IFT in carbonate reservoirs even in the presence of high salinity $(240 \mathrm{~g} / \mathrm{L}-\mathrm{NaCl}$ salinity) and thus enhance oil recovery from these lowpermeability reservoirs (Ghojavand et al. 2012). In another study by Sarafzadeh et al., the efficiency of two microbial biosurfactant-producing strains Enterobacter cloacae and Bacillus stearothermophilus SUCPM\#14 in EOR was tested (Sarafzadeh et al 2014). The core flood experiments investigated parameters such as cost effectivity, time and the ability of surfactants to lower IFT. It was found that of the strains, E. cloacae significantly reduced the IFT of water/crude oil system from 30 to $2.7 \mathrm{mN} / \mathrm{m}$, modifying the capillary numbers and mobilizing trapped oil.

Sometimes, natural surfactants extracted from plant sources can also function as an effective chemical EOR agent. Based on studies concerning its adsorption and economic aspects, saponin was found to be an important EOR agent, having very low cost and low adsorption values comparable to commercial, industrial surfactants for carbonate reservoirs (Ahmadi and Shadizadeh 2012; Shahri et al. 2012; Zendehboudi et al. 2013). In their studies, Ahmadi and Shadizadeh systematically investigated the implementation of a novel sugar-based surfactant derived from the leaves of $Z$. spina christi for EOR applications in carbonate reservoirs (Ahmadi and Shadizadeh 2013b). Under the optimum conditions of $8 \mathrm{wt} \%$ surfactant concentrations and 15,000 ppm salinity, the proposed surfactant exhibited $81 \%$ oil recovery.

\subsubsection{Viscoelastic surfactants}

Recently introduced viscoelastic surfactants are suggested as an alternative to polymers. They are known to effectively enhance oil recovery from carbonate reservoirs under conditions of high temperature and salinity (Azad and Sultan 2010; Sultan et al. 2014). Viscoelastic surfactants are very promising waterborne chemicals that combine the desirable properties of surfactants and water viscosifiers. Similar to conventional surfactants, they are also amphiphilic in nature with a hydrophilic and a hydrophobic portion. However, unlike surfactants that form spherical micelles of oil in water, viscoelastic surfactants aggregate to form large complex supramolecular structures that have a high viscosity. A primary benefit of these supramolecules is that they possess self-healing capability, unlike polymers. Usually, the structure and size of these viscoelastic surfactants are determined by the surfactant head group size, charge of the surfactant, temperature, salinity and flow conditions. With an increase in concentration, these surfactant molecules create "worm-like" micelles when the surfactant molecule forms long anisometric flexible structures that are capable of entangling with other "worm" structures (Santvoort and Golombok 2015). One of the possible issues of implementing viscoelastic surfactants is adsorption on the carbonate surface, which, however, can be managed in high-pH alkaline systems. Others may include their emulsification with oil and losing their viscosity, high cost and rather fragile nature of viscofying structures. Effects of shear, maintenance of viscosity during flow, injectivity and industrialscale production and availability are also required to be evaluated for commercial success.

\subsection{Surfactant-based EOR projects}

A few surfactant-based EOR projects have been tried in carbonate fields, although many polymer projects were conducted between the 1960s-1990s. Between 1990s and 2000s, only few surfactant stimulation studies were reported in carbonate reservoirs; including Yates field in Texas and the Cotton Wood Creek in Wyoming. The Baturaja Formation in the Semoga field in Indonesia is a comparatively recent field study.

A list of published field studies on surfactant-based chemical EOR for carbonate reservoirs is summarized in Table 1.

\section{Surfactants employed for chemical EOR studies in carbonate reservoirs over the years}

Although there are very few reported field projects for cEOR in carbonate reservoirs, research activities about chemical methods have always been and are still in progress through joint industrial projects and various academic institution initiatives. Table 2 summarizes a list of published laboratory studies on cEOR by surfactants, alkaline surfactants, and alkaline surfactant polymer mixtures. Apart from this, some of the recently introduced surfactants 
Table 1 A selection of published surfactant-based chemical EOR field projects for carbonate reservoirs

\begin{tabular}{|c|c|c|c|c|c|c|c|c|}
\hline \multirow[t]{2}{*}{ Field } & \multirow[t]{2}{*}{ Region } & \multirow[t]{2}{*}{ Start } & \multicolumn{2}{|c|}{ Oil characteristics } & \multirow{2}{*}{$\begin{array}{l}\text { Oil } \\
\text { recovery, } \\
\% \text { OOIP }\end{array}$} & \multirow[t]{2}{*}{ Chemicals used } & \multirow{2}{*}{$\begin{array}{l}\text { Process } \\
\text { adopted/comments }\end{array}$} & \multirow[t]{2}{*}{ References } \\
\hline & & & $\mathrm{API}^{\circ}$ & $\begin{array}{l}\text { Viscosity, } \\
\mathrm{cP}\end{array}$ & & & & \\
\hline $\begin{array}{l}\text { Wichita } \\
\text { County } \\
\text { Regular } \\
\text { Gunsight } \\
\text { reservoir }\end{array}$ & Texas & $\begin{array}{l}10 / 1 / \\
1975\end{array}$ & 40.0 & 3.2 & 22.0 & $\begin{array}{l}\text { Surfactants: petroleum } \\
\text { sulfonates }+ \text { alkyl ether } \\
\text { sulfate } \\
\text { Polymers: polyacrylamide }\end{array}$ & $\begin{array}{l}\text { Micellar/polymer } \\
\text { flooding process } \\
\text { adopted } \\
\text { (secondary } \\
\text { recovery) } \\
\text { Reservoir } \\
\text { temperature: } \\
31.6^{\circ} \mathrm{C}\end{array}$ & Leonard (1984) \\
\hline $\begin{array}{l}\text { Wesgum } \\
\text { field, } \\
\text { Smackover } \\
\text { reservoir }\end{array}$ & Arkansas & $6 / 1980$ & 21.0 & 11.0 & 26.7 & $\begin{array}{l}\text { Surfactants: petroleum } \\
\text { sulfonates }+ \text { alkyl ether } \\
\text { sulfate } \\
\text { Polymers: polyacrylamide }\end{array}$ & $\begin{array}{l}\text { Micellar/polymer } \\
\text { flooding process } \\
\text { adopted } \\
\text { (secondary } \\
\text { recovery) } \\
\text { Reservoir } \\
\text { temperature: } \\
85^{\circ} \mathrm{C}\end{array}$ & Leonard (1986) \\
\hline $\begin{array}{l}\text { Bob Slaughter } \\
\text { Block } \\
\text { Lease, San } \\
\text { Andres } \\
\text { reservoir }\end{array}$ & Texas & 1980 & 31.4 & 1.3 & 12.0 & $\begin{array}{l}\text { Non-emulsion formulation: } \\
1.5 \% \text { solubilizer A } \\
\text { (alkyl ether sulfates) and } \\
3.5 \% \text { Witco petroleum } \\
\text { sulfonate } \\
\text { Emulsion formulation: } \\
1.46 \% \text { solubilizer B } \\
\text { (alkyl aryl ether sulfates), } \\
3.6 \% \text { Witco petroleum } \\
\text { sulfonate, } 0.95 \% \\
\text { synthetic sulfonate, } 4 \% \\
\text { gas oil, } 4 \% \text { slaughter } \\
\text { crude oil }\end{array}$ & $\begin{array}{l}\text { Two surfactant/ } \\
\text { polymer flooding } \\
\text { processes } \\
\text { adopted: non- } \\
\text { emulsion } \\
\text { formulation and } \\
\text { emulsion } \\
\text { formulation } \\
\text { Reservoir } \\
\text { temperature: } \\
43{ }^{\circ} \mathrm{C}\end{array}$ & $\begin{array}{l}\text { Adams and } \\
\text { Schievelbein } \\
(1987)\end{array}$ \\
\hline Isenhour & $\begin{array}{l}\text { Wyoming, } \\
\text { USA }\end{array}$ & 1980 & 43.1 & 4.8 & 26.4 & $\begin{array}{l}\mathrm{Na}_{2} \mathrm{CO}_{3}+\text { anionic } \\
\text { polymers }\end{array}$ & $\begin{array}{l}\text { Alkali/polymer } \\
\text { flooding process } \\
\text { adopted } \\
\text { Reservoir } \\
\text { temperature: } \\
36.1^{\circ} \mathrm{C}\end{array}$ & Doll (1988) \\
\hline $\begin{array}{l}\text { Cambridge } \\
\text { Minnelusa }\end{array}$ & $\begin{array}{l}\text { Wyoming, } \\
\text { USA }\end{array}$ & 1993 & 20.0 & 31.0 & 36.0 & $\begin{array}{l}1.25 \mathrm{wt} \% \mathrm{Na}_{2} \mathrm{CO}_{3} \text { as } \\
\text { alkali }+0.1 \mathrm{wt} \% \\
\text { Petrostep B-100 as } \\
\text { surfactant }+1475 \mathrm{mg} / \mathrm{L} \\
\text { Alcoflood1175A as } \\
\text { polymer }\end{array}$ & $\begin{array}{l}\text { Alkaline/surfactant/ } \\
\text { polymer flooding } \\
\text { process adopted } \\
\text { (secondary } \\
\text { recovery) } \\
\text { Reservoir } \\
\text { temperature: } \\
55.6^{\circ} \mathrm{C}\end{array}$ & $\begin{array}{l}\text { Vargo et al. } \\
\quad(2000)\end{array}$ \\
\hline $\begin{array}{l}\text { Yates field, } \\
\text { San Andres } \\
\text { reservoir }\end{array}$ & Texas & 1998 & 30.0 & 6 & 15.0 & $\begin{array}{l}0.3 \%-0.4 \% \text { nonionic } \\
\text { ethoxy alcohol (Shell } \\
91-8 \text { ) surfactant and } \\
\text { 35\% Stepan CS-460 } \\
\text { anionic ethoxy sulfate } \\
\text { surfactant }\end{array}$ & $\begin{array}{l}\text { Surfactant well } \\
\text { stimulation } \\
\text { processes } \\
\text { adopted } \\
\text { Single-well Huff-n- } \\
\text { Puff dilute } \\
\text { surfactant } \\
\text { treatment } \\
\text { Reservoir } \\
\text { temperature: } \\
28{ }^{\circ} \mathrm{C}\end{array}$ & $\begin{array}{l}\text { Yang and } \\
\text { Wadleigh } \\
\text { (2000), } \\
\text { Mathiassen } \\
\text { (2003) }\end{array}$ \\
\hline
\end{tabular}


Table 1 continued

\begin{tabular}{|c|c|c|c|c|c|c|c|c|}
\hline \multirow[t]{2}{*}{ Field } & \multirow[t]{2}{*}{ Region } & \multirow[t]{2}{*}{ Start } & \multicolumn{2}{|c|}{ Oil characteristics } & \multirow{2}{*}{$\begin{array}{l}\text { Oil } \\
\text { recovery, } \\
\% \text { OOIP }\end{array}$} & \multirow[t]{2}{*}{ Chemicals used } & \multirow{2}{*}{$\begin{array}{l}\text { Process } \\
\text { adopted/comments }\end{array}$} & \multirow[t]{2}{*}{ References } \\
\hline & & & $\mathrm{API}^{\circ}$ & $\begin{array}{l}\text { Viscosity, } \\
\mathrm{cP}\end{array}$ & & & & \\
\hline $\begin{array}{l}\text { Mauddud } \\
\text { carbonate } \\
\text { reservoir }\end{array}$ & Bahrain & $\begin{array}{l}1 / 2000 \\
1 / 2002\end{array}$ & - & $1.4-2.9$ & $10-15$ & $\begin{array}{l}0.5 \% \text { of surfactants in } 200 \\
\text { gallons per } \mathrm{ft} \text { of diesel } \\
\text { oil } \\
0.5 \% \text { of surfactants in } 55 \\
\text { gallons per } \mathrm{ft} \text { of xylene } \\
0.5 \% \text { of surfactants }+1 \% \\
\text { sodium carbonate } \\
\text { alkaline solution }\end{array}$ & $\begin{array}{l}\text { Surfactant diesel } \\
\text { wash } \\
\text { Surfactant xylene } \\
\text { wash } \\
\text { Alkaline surfactant } \\
\text { flooding process } \\
\text { adopted } \\
\text { Reservoir } \\
\text { temperature: } \\
60^{\circ} \mathrm{C}\end{array}$ & $\begin{array}{l}\text { Zubari and } \\
\text { Sivakumar } \\
\text { (2003) }\end{array}$ \\
\hline $\begin{array}{l}\text { Cottonwood } \\
\text { Creek field, } \\
\text { Bighorn } \\
\text { Basin }\end{array}$ & $\begin{array}{l}\text { Wyoming, } \\
\text { USA }\end{array}$ & 1999 & 27 & 2.8 & 10.4 & $\begin{array}{l}\text { Nonionic polyoxyethylene } \\
\text { alcohol (POA) }\end{array}$ & $\begin{array}{l}\text { Single-well } \\
\text { surfactant } \\
\text { stimulation } \\
\text { process adopted } \\
\text { Reservoir } \\
\text { temperature: } \\
65.5^{\circ} \mathrm{C}\end{array}$ & $\begin{array}{l}\text { Xie et al. } \\
\text { (2004), } \\
\text { Weiss et al. } \\
(2006)\end{array}$ \\
\hline $\begin{array}{c}\text { Semoga field, } \\
\text { Baturaja } \\
\text { Formation }\end{array}$ & Indonesia & 2009 & 38 & 0.84 & $\begin{array}{l}58,000 \text { bbl } \\
\text { over a } \\
\text { period of } \\
3 \text { months }\end{array}$ & Nonionic surfactants & $\begin{array}{l}\text { Surfactant well } \\
\text { stimulation via } \\
\text { Huff-n-Puff } \\
\text { processes } \\
\text { adopted } \\
\text { Operation in } 3 \\
\text { steps: (a) pre- } \\
\text { flush, (b) main } \\
\text { flush and } \\
\text { (c) overflush } \\
\text { Reservoir } \\
\text { temperature: } \\
83{ }^{\circ} \mathrm{C} \text {; salinity: } \\
15,000 \mathrm{mg} / \mathrm{L}\end{array}$ & $\begin{array}{l}\text { Rilian et al. } \\
\text { (2008) }\end{array}$ \\
\hline
\end{tabular}

targeting specific carbonate reservoir conditions such as high temperature, high salinity and the presence of natural fractures have been discussed in detail.

\subsection{Surfactants targeted toward high-temperature high-salinity (HTHS) reservoirs of the Middle East}

The high temperature of about $120{ }^{\circ} \mathrm{C}$ in oil to mixed-wet carbonate reservoirs around the Middle East and elsewhere is an important criterion to be considered when looking for appropriate surfactants for cEOR. The high salinities such as 16\%-22\% TDS in Abu Dhabi along with the high temperature in the range of $120{ }^{\circ} \mathrm{C}$ are current challenges in the implementation of cEOR in the United Arab Emirates (Quadri et al. 2015). The viscosities of dead crude oils and crude oils containing dissolved gasses (saturated and under saturated) from the Middle East were accurately calculated using the Elsharkawy and Alikhan model (Elsharkawy and Alikhan 1999) for the formation evaluation of hydrocarbon reserves, for studying fluid flow through porous media and for designing production equipment. The dead oil viscosity $(0.6-33.7 \mathrm{cP})$, saturated oil viscosity $(0.05-20.89 \mathrm{cP})$ and undersaturated oil viscosity (0.2-5.7 cP) having API gravity of 19.9-48, temperatures of $38-150{ }^{\circ} \mathrm{C}$, bubble point pressure of $690-25,500 \mathrm{kPa}$ and pressure above bubble point $(8875-69,000 \mathrm{kPa})$ were obtained from the Middle East crude oils.

For such challenging reservoirs, an approach using tetraalkylammonium salt (TAS) type cationic surfactant was proposed for enhancing ORF from heavy oil-impregnated calcite cores (Saleh et al. 2008). It is commonly observed that spontaneous water imbibition is not possible in oil-wet rock surfaces due to the presence of very small or negative capillary pressure. Initially, it was believed that wettability reversal by anionic ethoxylated sulfonate surfactants was capable of achieving spontaneous imbibition of water by capillary forces in the new water-wetted surfaces (Standnes and Austad 2000a). Nevertheless, low 20\% ORF values obtained from experiments using anionic 
Table 2 Chemical EOR laboratory studies for carbonate reservoirs by surfactants, alkaline surfactants and ASP mixed slugs

\begin{tabular}{|c|c|c|c|c|c|}
\hline $\begin{array}{l}\text { Surfactant type and } \\
\text { concentration }\end{array}$ & Materials & Synthetic brine & $\begin{array}{l}\text { Comments/experimental } \\
\text { outcomes }\end{array}$ & $\begin{array}{l}\text { Estimated } \\
\text { final } \\
\text { recovery, } \\
\%\end{array}$ & References \\
\hline $\begin{array}{l}\text { Amphoteric Petrostep B-100 } \\
\text { surfactant }(0.2 \mathrm{wt} \%- \\
0.5 \mathrm{wt} \%)+ \text { Pusher } 700 \mathrm{E} \\
\text { polymer } \\
(0.12 \mathrm{wt} \%)+\text { sodium } \\
\text { tripolyphosphate }(0.4 \%- \\
0.5 \%) \text { and sodium } \\
\text { carbonate }(2 \%) \text { alkali }\end{array}$ & $\begin{array}{l}\text { Cretaceous } \\
\text { Upper } \\
\text { Edwards } \\
\text { reservoir } \\
\text { Carbonate } \\
\text { formations } \\
\text { from Central } \\
\text { Texas } \\
\text { Permeability: } \\
75 \mathrm{mD}\end{array}$ & $\begin{array}{l}\text { Formation brine (TDS- } \\
12,000 \mathrm{ppm}, \mathrm{Ca}^{2+}, \mathrm{Mg}^{2+} \\
\mathrm{Na}^{+} \text {) }\end{array}$ & $\begin{array}{l}\text { Experiments conducted at } \\
\text { reservoir temperature of } \\
42{ }^{\circ} \mathrm{C} \\
\text { Crude oil viscosity: } 3 \mathrm{cP} \text {; } \\
\text { API: } 27^{\circ} \text { (light oil) } \\
\text { ASP flooding was adopted }\end{array}$ & 45 & $\begin{array}{l}\text { Olsen et al. } \\
\text { (1990) }\end{array}$ \\
\hline $\begin{array}{l}\text { Cationic surfactants of the } \\
\text { type tetra alkyl ammonium } \\
\text { (six) } \\
\text { Anionic surfactants (eight) } \\
0.1 \mathrm{wt} \% \text { for each }\end{array}$ & $\begin{array}{l}\text { Oil-wet low } \\
\text { permeability } \\
(2-7 \mathrm{mD}) \\
\text { outcrop chalk } \\
\text { from Stevns } \\
\text { Klint } \\
\text { Copenhagen }\end{array}$ & $\begin{array}{l}\text { Three different brines with } \\
\text { various dissolved solids } \\
\text { content }\left(\mathrm{Na}^{+}, \mathrm{K}^{+}, \mathrm{Mg}^{2+}\right. \\
\left.\mathrm{Ca}^{2+}, \mathrm{Cl}^{-}, \mathrm{SO}_{4}{ }^{2-}, \mathrm{HCO}_{3}{ }^{-}\right)\end{array}$ & $\begin{array}{l}\text { Two types of oil are used: Oil } \\
\text { A-acidic crude oil: } n \text { - } \\
\text { heptane }(60: 40) \text { and Oil } \\
\text { B-pure } n \text {-heptane } \\
\text { Imbibition tests run with } \\
\text { cationic and anionic } \\
\text { surfactants at different } \\
\text { temperatures }\left(40-70{ }^{\circ} \mathrm{C}\right) \\
\text { Cationic surfactants have a } \\
\text { higher potential to expel oil } \\
\text { from oil-wet chalk material } \\
\text { (irreversible wettability } \\
\text { alteration) than anionic } \\
\text { surfactants } \\
\text { Surfactant concentration } \\
>\text { CMC }\end{array}$ & $10-75$ & $\begin{array}{l}\text { Standnes } \\
\text { and } \\
\text { Austad } \\
\text { (2003) }\end{array}$ \\
\hline $\begin{array}{l}\text { Anionic (ethoxylated and } \\
\text { propoxylated sulfate) } \\
\text { surfactants }+ \text { sodium } \\
\text { carbonate alkali mixture } \\
(0.05 \mathrm{wt} \%-0.1 \mathrm{wt} \%)\end{array}$ & $\begin{array}{l}\text { Dolomite cores } \\
\text { Permeability: } \\
\text { 40-122 mD }\end{array}$ & $\begin{array}{l}\text { Formation brines }(\mathrm{NaCl}, \mathrm{KCl} \text {, } \\
\left.\qquad \mathrm{CaCl}_{2}, \mathrm{MgCl}_{2}, \mathrm{Na}_{2} \mathrm{SO}_{4}\right)\end{array}$ & $\begin{array}{l}\text { Anionic surfactants and } \\
\mathrm{Na}_{2} \mathrm{CO}_{3} / \mathrm{NaHCO}_{3} \text { changed } \\
\text { the wettability of oil-wet } \\
\text { dolomite cores to } \\
\text { preferentially water-wet as } \\
\text { a function of the prior aging } \\
\text { temp in crude oil } \\
\text { Oil recovery from oil-wet } \\
\text { dolomite cores was by } \\
\text { spontaneous imbibition with } \\
\text { an alkaline anionic } \\
\text { surfactant solution } \\
\text { Oil viscosity: } 18.1-22.6 \mathrm{cP}\end{array}$ & $40-50$ & $\begin{array}{l}\text { Hirasaki } \\
\text { and } \\
\text { Zhang } \\
\text { (2003) }\end{array}$ \\
\hline
\end{tabular}


Table 2 continued

\begin{tabular}{|c|c|c|c|c|c|}
\hline $\begin{array}{l}\text { Surfactant type and } \\
\text { concentration }\end{array}$ & Materials & Synthetic brine & $\begin{array}{l}\text { Comments/experimental } \\
\text { outcomes }\end{array}$ & $\begin{array}{l}\text { Estimated } \\
\text { final } \\
\text { recovery, } \\
\%\end{array}$ & References \\
\hline $\begin{array}{l}\text { Nonionic ethoxy alcohol } \\
\text { surfactants }(<3500 \mathrm{ppm})\end{array}$ & Dolomite cores & $\begin{array}{l}\text { Actual Yates reservoir brine } \\
\quad\left(\mathrm{NaCl}_{1} \mathrm{KCl}, \mathrm{CaCl}_{2}, \mathrm{MgCl}_{2} \text {, }\right. \\
\left.\mathrm{Na}_{2} \mathrm{SO}_{4}, \mathrm{NaHCO} \mathrm{HCO}_{3}\right) \text { supplied } \\
\text { by Marathon Oil Company. } \\
\text { Synthetic brine (prepared as } \\
\text { per the same composition) }\end{array}$ & $\begin{array}{l}\text { Nonionic ethoxy alcohol } \\
\text { surfactants decreased IFT } \\
\text { between Yates crude oil } \\
\text { and Yates brine, along with } \\
\text { a simultaneous decrease in } \\
\text { contact angle from } 156^{\circ} \\
\text { (strongly oil-wet) to } 39^{\circ} \\
\text { (water-wet) } \\
\text { The experimental study } \\
\text { identified two simple } \\
\text { techniques of surfactant } \\
\text { addition and brine dilution } \\
\text { to beneficially alter the } \\
\text { wettability of oil-wet } \\
\text { fractured cores and } \\
\text { minimize capillary trapping } \\
\text { of crude oil in reservoir } \\
\text { rocks }\end{array}$ & - & $\begin{array}{l}\text { Vijapurapu } \\
\text { and Rao } \\
\text { (2004) }\end{array}$ \\
\hline $\begin{array}{l}\text { Anionic ethoxylated }(\mathrm{EO}) \text { and } \\
\text { propoxylated }(\mathrm{PO}) \text { sulfate } \\
\text { surfactants } \\
\text { Cationic (CTAB) surfactants } \\
0.05 \mathrm{wt} \% \text { for each }\end{array}$ & $\begin{array}{l}\text { Calcite } \\
\text { lithographic } \\
\text { limestone, } \\
\text { marble, } \\
\text { dolomite } \\
\text { plates }\end{array}$ & Synthetic brine $\left(\mathrm{Na}_{2} \mathrm{CO}_{3}\right)$ & $\begin{array}{l}\text { The oil used was West Texas } \\
\text { fractured carbonate field } \\
\text { crude oil ( } 19.1 \mathrm{cP}, \text { API } \\
28.2^{\circ} \text {-light) supplied by } \\
\text { Marathon Oil Company } \\
\text { In the presence of } \mathrm{Na}_{2} \mathrm{CO}_{3} \text {, } \\
\text { anionic surfactants could } \\
\text { change the calcite } \\
\text { wettability of carbonate } \\
\text { from oil-wet to water-wet, } \\
\text { similar to or even better } \\
\text { than cationic surfactants } \\
\text { The adsorption of anionic } \\
\text { sulfonate surfactants is } \\
\text { significantly suppressed by } \\
\text { the addition of } \mathrm{Na}_{2} \mathrm{CO}_{3}\end{array}$ & $35-55$ & $\begin{array}{l}\text { Seethepalli } \\
\text { et al. } \\
\text { (2004) }\end{array}$ \\
\hline $\begin{array}{l}\text { Cationic } \mathrm{C}_{12} \mathrm{TAB} \text { surfactants } \\
0.6 \mathrm{wt} \%-3.5 \mathrm{wt} \%\end{array}$ & $\begin{array}{l}\text { Oil-wet low } \\
\text { permeability } \\
(1-3 \mathrm{mD}) \\
\text { outcrop chalk } \\
\text { from Stevns } \\
\text { Klint } \\
\text { Copenhagen }\end{array}$ & Artificial seawater & $\begin{array}{l}\text { Crude oil used was diluted } \\
\text { with 40vol\% heptane } \\
\text { Oil viscosity: } 2.5 \mathrm{cP} \text { (light } \\
\text { oil) } \\
\text { Oil production from different } \\
\text { surfaces of the core studied } \\
\text { Comparison between the } \\
\text { gravity and capillary force } \\
\text { contribution }\end{array}$ & $50-90$ & $\begin{array}{l}\text { Hognesen } \\
\text { et al. } \\
\text { (2006) }\end{array}$ \\
\hline $\begin{array}{l}\text { Cationic } \mathrm{C}_{12} \mathrm{TAB} \text { surfactants } \\
\quad(1.0 \mathrm{wt} \%)\end{array}$ & $\begin{array}{l}\text { Outcrop chalk } \\
\text { Permeability low } \\
\quad(2-5 \mathrm{mD})\end{array}$ & $\begin{array}{l}\text { Artificial seawater as } \\
\text { reference, } 11 \text { different brines } \\
\text { with varying dissolved solid } \\
\text { contents }\left(\mathrm{Na}+, \mathrm{K}^{+}, \mathrm{Ca}^{2+}\right. \\
\mathrm{Mg}^{2+}, \mathrm{SCN}^{-}, \mathrm{SO}_{4}{ }^{2-}, \mathrm{Cl}^{-} \\
\left.\mathrm{HCO}_{3}{ }^{-}\right)\end{array}$ & $\begin{array}{l}\text { Oil A: } 60 \% \text { crude and } 40 \% \\
\text { heptane } \\
\text { Ion pair interaction is the } \\
\text { probable wettability } \\
\text { alteration factor, thereby } \\
\text { increasing the capillary } \\
\text { forces that facilitates } \\
\text { spontaneous imbibition of } \\
\text { oil } \\
\text { The temperature range in the } \\
\text { study was } 90-130^{\circ} \mathrm{C}\end{array}$ & $20-60$ & $\begin{array}{l}\text { Strand et al. } \\
\quad(2006)\end{array}$ \\
\hline
\end{tabular}


Table 2 continued

\begin{tabular}{|c|c|c|c|c|c|}
\hline $\begin{array}{l}\text { Surfactant type and } \\
\text { concentration }\end{array}$ & Materials & Synthetic brine & $\begin{array}{l}\text { Comments/experimental } \\
\text { outcomes }\end{array}$ & $\begin{array}{l}\text { Estimated } \\
\text { final } \\
\text { recovery, } \\
\%\end{array}$ & References \\
\hline $\begin{array}{l}\text { Five anionic (sulfonate, } \\
\text { disulfonate and sulfate) } \\
\text { surfactants } \\
\text { Two nonionic (ethoxylates) } \\
\text { surfactants, } 0.1 \mathrm{wt} \% \text { for each }\end{array}$ & $\begin{array}{l}\text { Calcite plates } \\
\text { limestone } \\
\text { cores, } \\
\text { Permeability: } \\
15 \mathrm{mD}\end{array}$ & $\mathrm{Na}_{2} \mathrm{CO}_{3}$ and $\mathrm{NaCl}$ & $\begin{array}{l}\text { The oil used was West Texas } \\
\text { fractured carbonate field } \\
\text { crude oil ( } 23.8 \mathrm{cP} \text {, API } \\
28.2^{\circ} \text {-light) at } 27{ }^{\circ} \mathrm{C} \\
\text { The temperature ranges: } \\
25-90^{\circ} \mathrm{C} \\
\text { Oil recovery rate increases } \\
\text { with temperature increase } \\
\text { for all anionic and nonionic } \\
\text { surfactants studied up to } \\
90{ }^{\circ} \mathrm{C} \\
\text { Surfactant/brine imbibition } \\
\text { was a gravity driven process }\end{array}$ & $60-75$ & $\begin{array}{l}\text { Gupta and } \\
\text { Mohanty } \\
2010\end{array}$ \\
\hline $\begin{array}{l}\text { Anionic (sulfonate, } \\
\text { disulfonate and sulfate) } \\
\text { surfactants, } 0.1 \mathrm{wt} \%-5 \mathrm{wt} \%\end{array}$ & $\begin{array}{l}\text { Calcite plates } \\
\text { Texas } \\
\text { Cordova } \\
\text { cream } \\
\text { limestone core } \\
\text { Permeability: } \\
15 \mathrm{mD}\end{array}$ & $\begin{array}{l}\text { Synthetic brine }\left(\mathrm{Na}_{2} \mathrm{SO}_{4},\right. \\
\mathrm{NaCl}, \mathrm{Na}_{2} \mathrm{CO}_{3}, \mathrm{CaCl}_{2}, \\
\left.\mathrm{MgCl}_{2}\right)\end{array}$ & $\begin{array}{l}\text { Two oils used: (a) Model oil- } \\
1.5 w t \% \text { of cyclohexane } \\
\text { pentanoic acid }+n \text {-decane. } \\
\text { (b) West Texas fractured } \\
\text { carbonate field crude oil } \\
\left(23.8 \mathrm{cP}, \text { API } 28.2^{\circ} \text {-light) }\right. \\
\text { at } 27^{\circ} \mathrm{C} \\
\text { Optimum surfactant } \\
\text { concentration is directly } \\
\text { linked with brine salinity } \\
\text { Mixed with } \mathrm{Na}_{2} \mathrm{CO}_{3} \text {, anionic } \\
\text { surfactants desorb the } \\
\text { naphthenic acid from } \\
\text { carbonate surface, as at high } \\
\text { pH, calcite charge is } \\
\text { switched from positive to } \\
\text { negative } \\
\text { Wettability of oil-aged calcite } \\
\text { altered by sulfate ions in the } \\
\text { presence of } \mathrm{Mg}^{2+}, \mathrm{Ca}^{2+} \text { at } \\
90{ }^{\circ} \mathrm{C} \text { aiding in oil recovery }\end{array}$ & $30-50$ & $\begin{array}{l}\text { Gupta and } \\
\text { Mohanty } \\
\text { (2011) }\end{array}$ \\
\hline $\begin{array}{l}\text { Two anionic surfactants } \\
\text { (ethoxylated sulfonate: } \\
\text { AV-70, AV-150) }\end{array}$ & Limestone & \multirow[t]{4}{*}{$\begin{array}{l}\text { Formation brine }(\mathrm{NaCl} \text {, } \\
\left.\qquad \mathrm{MaCl}_{2}\right)\end{array}$} & $\begin{array}{l}\text { The mixture of cationic and } \\
\text { nonionic surfactants is } \\
\text { stable at high temperatures }\end{array}$ & \multirow[t]{4}{*}{$70-80$} & \multirow[t]{4}{*}{$\begin{array}{l}\text { Sharma and } \\
\text { Mohanty } \\
\text { (2013) }\end{array}$} \\
\hline $\begin{array}{l}\text { Three nonionic surfactants } \\
\text { (NP ethoxylate, 15-s- } \\
\text { ethoxylate, TDA 30EO) }\end{array}$ & & & $\begin{array}{l}\left(100^{\circ} \mathrm{C}\right) \text { and high salinity } \\
\text { Effective in wettability } \\
\text { alteration of carbonate }\end{array}$ & & \\
\hline $\begin{array}{l}\text { Four cationic surfactants } \\
\text { (CTAB, DTAB, Arquad } \\
\text { C-50, Arquad T-50) } \\
\text { surfactants }\end{array}$ & & & $\begin{array}{l}\text { reservoirs with aging } \\
1-2 \text { months }\end{array}$ & & \\
\hline$<0.2 \mathrm{wt} \%$ for each & & & & & \\
\hline
\end{tabular}


Table 2 continued

\begin{tabular}{|c|c|c|c|c|c|}
\hline $\begin{array}{l}\text { Surfactant type and } \\
\text { concentration }\end{array}$ & Materials & Synthetic brine & $\begin{array}{l}\text { Comments/experimental } \\
\text { outcomes }\end{array}$ & $\begin{array}{l}\text { Estimated } \\
\text { final } \\
\text { recovery, } \\
\%\end{array}$ & References \\
\hline $\begin{array}{l}\text { Anionic surfactants: alkyl } \\
\text { propoxy (PO) sulfates } \\
\text { (APS) and their blends with } \\
\text { internal olefin sulfonates } \\
\text { (IOS), alkyl benzene } \\
\text { sulfonate (ABS), alkyl } \\
\text { xylene sulfonate (AXS) }\end{array}$ & $\begin{array}{l}\text { Silurian } \\
\text { Dolomite } \\
\text { outcrop cores } \\
\text { Permeability: } \\
195 \mathrm{mD}\end{array}$ & $\begin{array}{l}\text { Formation brine } \\
\qquad(\mathrm{TDS}=9412-10,625 \mathrm{ppm}, \\
\mathrm{Na}^{+}, \mathrm{Mg}^{2+}, \mathrm{Ca}^{2+}, \mathrm{Cl}^{-} \\
\left.\mathrm{SO}_{4}{ }^{2-}, \mathrm{HCO}_{3}{ }^{-}\right)\end{array}$ & $\begin{array}{l}\text { Crude oil viscosity: } 22.5 \mathrm{cP} \text {; } \\
\text { API: } 28.2^{\circ} \text { (light oil) } \\
\text { The experiments were } \\
\text { conducted at low } \\
\text { temperatures }\left(\sim 25{ }^{\circ} \mathrm{C}\right) \\
\text { and salinity of } \\
\sim 11,000 \text { ppm TDS }\end{array}$ & $26-80$ & $\begin{array}{l}\text { Sagi et al. } \\
\quad(2013)\end{array}$ \\
\hline $0.25 \mathrm{wt} \%-2.0 \mathrm{wt} \%$ & & & $\begin{array}{l}\text { The anionic surfactant blends } \\
\text { produced optimal salinity } \\
\text { close to reservoir salinity } \\
\text { and achieved oil recovery } \\
\text { efficiencies of }>75 \% \text { at } \\
0.5 \mathrm{wt} \% \text { of surfactant } \\
\text { concentration }\end{array}$ & & \\
\hline $\begin{array}{l}\text { Two anionic and two } \\
\text { nonionic surfactants }[0.2,1 \\
\text { and } 2 \text { gallons per thousand } \\
\text { gallons (gpt)] }\end{array}$ & $\begin{array}{l}\text { Siliceous and } \\
\text { carbonate } \\
\text { shale cores }\end{array}$ & Water & $\begin{array}{l}\text { Crude oil viscosity: } \\
30-40.5 \mathrm{cP} \text {; API: } 35.77^{\circ}- \\
37.74^{\circ} \\
\text { Both anionic and nonionic } \\
\text { surfactants changed the } \\
\text { wettability of carbonate } \\
\text { shale cores } \\
\text { Anionic surfactants } \\
\text { performed better than } \\
\text { nonionic surfactants in } \\
\text { changing contact angles in } \\
\text { oil shale samples }\end{array}$ & - & $\begin{array}{l}\text { Alvarez } \\
\quad \text { et al. } \\
\text { (2014) }\end{array}$ \\
\hline $\begin{array}{l}\text { Anionic Guerbet alkoxy } \\
\text { carboxylate (GAC) } \\
\text { surfactants }(0.15 \mathrm{wt} \%- \\
1.0 \mathrm{wt} \%)\end{array}$ & $\begin{array}{l}\text { Silurian dolomite } \\
\qquad(478 \mathrm{mD}) \\
\text { Estaillade } \\
\text { limestone core } \\
(187 \mathrm{mD})\end{array}$ & $\begin{array}{l}\text { Formation brine (TDS- } \\
23,800 \mathrm{ppm} \text {, divalent cation } \\
\text { concentration } 3700 \mathrm{ppm} \text { ) }\end{array}$ & $\begin{array}{l}\text { Crude oil viscosity: } 0.5 \mathrm{cP} \text {, } \\
\text { API: } 34^{\circ} \text { (light oil) } \\
\text { The GAC surfactants reduced } \\
\text { IFT significantly } \\
\text { The GAC can act as } \\
\text { alternatives to sulfate } \\
\text { surfactants for high-salinity, } \\
\text { high-temperature reservoirs } \\
\text { where alkali is not included } \\
\text { in the formulation }\end{array}$ & $90-94.5$ & $\begin{array}{l}\text { Lu et al. } \\
\qquad(2014 \mathrm{a})\end{array}$ \\
\hline $\begin{array}{l}\text { Nonionic branched } \\
\text { nonylphenol ethoxylates } \\
\text { (Huntsman SURFONICS } \\
\text { N-120 \& Huntsman } \\
\text { SURFONICS N-150) and } \\
\text { branched isotridecyl } \\
\text { ethoxylate (Huntsman } \\
\text { SURFONICS TDA-9) } \\
\text { surfactants } \\
\sim 0.07 \mathrm{wt} \%\end{array}$ & $\begin{array}{l}\text { SACROC } \\
\text { carbonate } \\
\text { cores } \\
\text { Permeability: } \\
13-16 \mathrm{mD}\end{array}$ & $\begin{array}{l}\mathrm{CO}_{2}, \mathrm{SACROC} \text { brine }(\mathrm{NaCl}, \\
\left.\quad \mathrm{CaCl}_{2}, \mathrm{MgCl}_{2}\right)\end{array}$ & $\begin{array}{l}\text { The surfactants are more } \\
\text { soluble in } \mathrm{CO}_{2} \text {, thus } \\
\text { forming stable } \mathrm{CO}_{2} \text {-in- } \\
\text { brine foams which appear } \\
\text { to be promising } \mathrm{CO}_{2} \\
\text { additives for mobility } \\
\text { control } \\
\text { They can act as appropriate } \\
\text { candidates for EOR } \\
\text { applications }\end{array}$ & - & $\begin{array}{l}\text { McLendon } \\
\text { et al. } \\
\text { (2014) }\end{array}$ \\
\hline
\end{tabular}

surfactants indicated that the desired wettability alteration is not always achieved. This finding leads to considering and testing of other surfactants of cationic nature. In their conjoint theoretical and experimental studies, Pons-Jimenez et al. (2014) proposed a plausible chemical mechanism involved in $36 \%$ ORF increase by the cationic surfactant dicecyltrimethylammonium chloride $\left(\mathrm{C}_{12} \mathrm{TAC}\right)$ at $150{ }^{\circ} \mathrm{C}$ on calcite, wetted by either heavy or light oil. The mechanism of action of $\mathrm{C}_{12}$ TAC on the ORF for heavy oil primarily involved oil disaggregation followed by viscosity decrease. Reduction in viscosity led to the release of oil that is loosely adsorbed onto the rock. However, there was no detectable wettability alteration of the carbonate reserves, in this case, confirming that both the asphaltenes 
and resins of crude oils remain strongly adsorbed on the rock surfaces, thereby maintaining the oil-wet state of carbonate rocks.

Recently, surfactant-aided gravity drainage process of oil recovery for water- as well as gas-flooded HTHS carbonate reservoirs was also tested. Sometimes, water flooding fails to perform successfully in heavily fractured carbonate rocks, where large viscous gradients cannot be imposed (Adibhatla and Mohanty 2008). In such cases, gas-aided gravity drainage is a conventional oil recovery technique. However, again when the permeability is low, the remaining oil saturation in such anticline-shaped reservoirs can be quite high and recovery annoyingly slow (Wang and Mohanty 2013). Herein comes the surfactant (anionic, nonionic and cationic) enhanced gravity drainage technique (Srivastava and Nguyen 2010; Ren et al. 2011; Guo et al. 2012). Cationic surfactants of the type alkyl trimethylammonium bromide $\left(\mathrm{C}_{n} \mathrm{TAB}\right)$ efficiently recovered approximately $70 \%$ of OOIP by imbibing water into originally oilwet chalks (Standnes and Austad 2000a, b, 2003). They were believed to form ion pairs with adsorbed organic carboxylates of the crude oil, solubilizing them into the oil and thereby changing the mixed/oil-wet rock surfaces to water-wet. This wettability alteration assisted in countercurrent imbibition of brine and led to increased oil recovery. However, the major drawbacks of this method are still the high surfactant concentration requirement along with its cost which leads to searches for newer cheaper cationic surfactants of the form $\mathrm{C}_{10} \mathrm{NH}_{2}$ (Adibhatla and Mohanty 2008). Another example of less expensive surfactants is the several bioderivatives of the coconut palm, termed Arquad and Dodigen (Strand et al. 2003). Several anionic surfactants under the commercial name Alfoterra and those mentioned in the works of Adibhatla and Mohanty (2008) were considered for gravity-aided methods in fractured carbonate formations. Anionic surfactants were known to diffuse into the matrix, lower the IFT and contact angle, which in turn decreases the capillary pressure and increase the oil relative permeability. The high relative permeability of oil helps the gravitational force in pulling the oil out of matrix (Hirasaki and Zhang 2003; Seethepalli et al 2004). As usual, the adsorption of anionic surfactants on the surface of calcite was suppressed with an increase in $\mathrm{pH}$ and a decrease in salinity.

\section{Overcoming challenges in EOR: future perspectives}

Over the last decade, a good number of technologies have been advanced to overcome many of the past failures and unlock new areas of research for challenging carbonate reservoirs. Nonetheless, it should be noted that despite some positive results from several experimental and pilot field studies, actual trials at exploration sites in a commercial setting are very limited (Adibhatla and Mohanty 2008). Lack of adequate practical knowledge about surfactants used in dual-porosity fractured carbonate reservoirs, limits their performance to a great extent (Manrique et al. 2007). In a few cases reported for surfactant-based cEOR for carbonate reservoirs, which include the Mauddud carbonate reservoir of Bahrain (Zubari and Sivakumar 2003), Yates field in Texas (Yang and Wadleigh 2000), Cottonwood Creek field in Wyoming (Xie et al. 2004) and the Baturaja Formation in the Semoga field of Indonesia (Rilian et al. 2008), the temperature was about $45^{\circ} \mathrm{C}$ and never higher. Therefore, much work remains to be accomplished for HTHS carbonate oil reserves to establish credible production baselines and successfully capture the recovered mobilized oil (Kiani et al. 2011).

Surfactant injection EOR for an oil-wet carbonate reservoir might not always be successful because of several reasons as outlined in the works of Kiani and coworkers. Their experimental findings suggested that in contrast to the homogeneous unfractured reservoirs, the pressure gradient in fractured formations may be too small to displace oil from the matrix. At times, several high-permeable fracture areas can act like "thief zones" and may bypass smaller fractures. To overcome such challenges, use of mobility control agents, for example foam, may be considered (Talebian et al. 2014, 2015). However, issues similar to foam stability in the presence of oil are still a challenge which requires much attention. More experiments on pseudo-emulsion physics and chemistry should be undertaken soon, where increased efforts should be made in the collection of more and more experimental data and correlating them with the stability of foams in oilsaturated carbonate reservoirs. Other parameters, such as salinity, temperature and wettability, must also be taken into account while designing future experiments. Another important parameter, which is very often neglected in analyzing foam stability in the presence of oil, is the disjoining pressure, which exists in very thin foam layers. For optimization of foam properties in contact with the oil phase, studies of the disjoining pressure in the pseudoemulsion films and its control are crucial, which remains a challenge.

Some of the typical problems encountered when polymers are used, especially during combined flooding strategies such as ASP flooding, include low injectivity or complete plugging of injection wells, degradation of polymers, incomplete polymer dissolution, and pump failures. Additionally, alkali and surfactant may cause corrosion, the formation of a persistent and stable emulsion between injected chemicals and oil and, most importantly, scaling (Bataweel and Nasr-El-Din 2011; Stoll et al 2010). 
Mineral scales are formed by deposition from aqueous solution of brine when they become supersaturated due to a change in their thermodynamic and chemical equilibrium i.e., ionic composition, $\mathrm{pH}$, pressure and temperature (Mackay et al. 2005). In oilfield operations, scaling is principally formed by a decrease in pressure and/or an increase in temperature of brine, which leads to the reduction in the solubility of salts. The alkalis react with ions $\left(\mathrm{Ca}^{2+}, \mathrm{CO}_{3}{ }^{2-}, \mathrm{SO}_{4}{ }^{2-}\right)$ of the carbonate minerals in the rock forming scales. Sometimes mixing of two incompatible brines (formation water rich in cations such as barium, calcium, strontium and sulfate-rich seawater) leads to precipitation of sulfate scales $\left(\mathrm{BaSO}_{4}\right)$ (Zahedzadeh et al. 2014). Scales damage well productivity by reducing permeability, plugging production lines, and fouling equipment, which leads to production-equipment failure, emergency shutdown with increased maintenance costs and decrease in overall production efficiency (Mackay and Jordan 2005). A traditional commercial approach to alleviate scaling in the oil and gas industry is by applying conventional hydrophilic scale inhibitors, for example, PPCA (polyphosphonocarboxylic acid) and DETPMP (diethylenetriaminepenta (methylene phosphonic acid)) (Bezemer and Bauer 1969). However, many of these organic phosphates and phosphonates that are widely used as scale inhibitors are highly toxic and unacceptable environmentally. Currently, new generation green scale inhibitors which minimize pollution associated with the manufacture and application of hazardous materials are being considered (Kumar et al. 2010). This study seems promising, and future investigations in optimizing favorable environment-friendly inhibitors should be encouraged for successful elimination of this challenging problem of carbonate formations.

Another significant difficulty for implementing surfactant EOR lies in its high adsorption on reservoir formations which needs continuous surfactant re-injection, rendering the designed EOR process inefficient and economically infeasible. The surface chemistry of most of the carbonate rocks significantly influences surfactant adsorption. Complex dissolution behavior is observed in certain minerals in carbonate rocks such as dolomite $\left(\mathrm{CaMg}\left(\mathrm{CO}_{3}\right)_{2}\right)$, calcite $\left(\mathrm{CaCO}_{3}\right)$ and magnesite $\left(\mathrm{MgCO}_{3}\right)$ (Hiorth et al. 2010). Interestingly, the isoelectric point of calcite is known to be dependent on the $\mathrm{pH}$ and sources of materials, equilibrium time and ionic strength in aqueous solutions (Ma et al. 2013). From their experimental simulations, Vdovic and Biscan stated that under the same ionic strength $\left(10^{-3} \mathrm{~mol} / \mathrm{dm}^{3} \mathrm{NaCl}\right)$ within the $\mathrm{pH}$ range of 7-11, natural calcite (Polycarb, ECC International) was more negatively charged than synthetic calcite (Socal-U1, Solvay, UK) (Vdovic and Biscan 1998). Experiments conducted by various groups of scientists studying adsorption behavior of both anionic (Ahmadall et al. 1993) and cationic surfactants (Rosen and $\mathrm{Li}$ 2001) over the calcite and dolomite surfaces arrived at the conclusion that the source of carbonate material seems to have a substantial impact on surfactant adsorption. Nevertheless, the search for newer cheaper surfactants and alkalis should be taken up. Efficient surfactant screening should be done for selecting the optimum surfactant for a system. Sometimes when a single surfactant fails to perform successfully for HTHS reservoirs, a dual-surfactant system may be a workable strategy.

Based on the recent analysis on the impact of water softening on the economics of cEOR, it was found that chemical cost can be decreased significantly by using soft sea water. Improved technologies are expected to come up in the near future which can reduce several operational and logistic issues of cEOR for carbonate reservoirs. There has to be a life-cycle approach to cEOR, and the concept of energizing the reservoir deserves attention from the earliest stages of field planning and development.

\section{Summary}

Fractured low-permeability carbonate reservoirs long drained by water and gas injections can have high remaining oil saturation. Surfactant EOR technologies targeted toward such reserves are considered versatile tertiary oil recovery techniques to maximize total oil production. Presently there are an increasing number of ongoing and planned cEOR evaluations at pilot scales globally. Though several publications on surfactant-assisted polymer, ASP, foam, microemulsions flooding experimental results on carbonate formations are available, there are very few field cases reported. Due to very challenging conditions of temperature and salinity, the availability of proper surfactants and polymers is severe limitation. Although switchable alkyl amine surfactants show promising results in laboratory tests for foam EOR, their application to field level still requires substantial effort. Surfactants and polymers for ASP, SP and polymer EOR applications are still not available to cater for the needs for HSHT carbonate reservoirs, though a few cationic surfactants showed promising results in wettability alteration experiments at laboratory scale. In addition to that, a laboratory and a field test show promising results but injection water used was of low salinity which seriously questions the application where low-salinity injection water is not available. As polymers are the primary requirement for mobility control in ASP and SP schemes, even if the surfactants become available, unavailability of suitable polymers is also a drawback in the development of 
EOR projects and development of suitable polymers should be considered as well. Design and operational experiences acquired from experimental findings should be exploited in developing newer methodologies for impacting global oil production significantly in the near future. To upgrade cEOR to the next level, there is an urgent need to develop better cEOR methods based on cost-effective, HTHS, environment-friendly chemicals. The latest findings as outlined in the current review significantly improve our knowledge in designing and standardizing cEOR techniques intended toward rugged carbonate reserves.

Open Access This article is distributed under the terms of the Creative Commons Attribution 4.0 International License (http://crea tivecommons.org/licenses/by/4.0/), which permits unrestricted use, distribution, and reproduction in any medium, provided you give appropriate credit to the original author(s) and the source, provide a link to the Creative Commons license, and indicate if changes were made.

\section{References}

Adams WT, Schievelbein VH. Surfactant flooding carbonate reservoirs. SPE Reserv Eng. 1987;2(4):619-26. doi:10.2118/12686PA.

Adibhatia B, Sun X, Muhanty K. Numerical studies of oil production from initially oil-wet fracture blocks by surfactant brine imbibition. In: SPE international improved oil recovery conference in Asia Pacific, December 5-6, Kuala Lumpur, Malaysia, 2005. doi:10.2118/97687-MS.

Adibhatla B, Mohanty KK. Oil recovery from fractured carbonates by surfactant-aided gravity drainage: laboratory experiments and mechanistic simulations. SPE Reserv Eval Eng. 2008;11(1):119-30. doi:10.2118/99773-PA.

Adkins SS, Chen X, Nguyen QP, et al. Effect of branching on the interfacial properties of nonionic hydrocarbon surfactants at the air-water and carbon dioxide-water interfaces. J Colloid Interface Sci. 2010;346(2):455-63. doi:10.1016/j.jcis.2009.12.059.

Ahmadall T, Gonzalez MV, Harwell JH, et al. Reducing surfactant adsorption in carbonate reservoirs. SPE Reserv Eng J. 1993;8(2):117-22. doi:10.2118/24105-PA.

Ahmadi MA, Shadizadeh SR. Adsorption of novel nonionic surfactant and particles mixture in carbonates: enhanced oil recovery implication. Energy Fuels. 2012;26(8):4655-63. doi:10.1021/ ef300154h.

Ahmadi MA, Shadizadeh SR. Experimental investigation of adsorption of a new nonionic surfactant on carbonate minerals. Fuel. 2013a;104:462-7. doi:10.1016/j.fuel.2012.07.039.

Ahmadi MA, Shadizadeh SR. Implementation of a high-performance surfactant for enhanced oil recovery from carbonate reservoirs. J Pet Sci Eng. 2013b;110:66-73. doi:10.1016/j.petrol.2013.07. 007.

Akbar M, Vissaparagada B, Alghamdi AH, et al. A snapshot of carbonate reservoir evaluation. Oilfield Rev. 2000;12(4):20-1.

Al-Mutairi SA, Kokal SL. EOR potential in the Middle East: current and future trends. In: SPE EUROPEC/EAGE annual conference and exhibition, May 23-26, Vienna, Austria, 2011. doi:10.2118/ 143287-MS

Al-Sulaimani HS, Al-Wahaibi YM, Al-Bahry S, et al. Experimental investigation of biosurfactants produced by bacillus species and their potential for MEOR in Omani oil field. In: SPE EOR conference at oil \& gas West Asia, April 11-13, Muscat, Oman, 2010. doi:10.2118/129228-MS.

Alvarado V, Manrique E. Enhanced oil recovery: an update review. Energies. 2010;3(9):1529.

Alvarez JO, Neog A, Jais A, et al. Impact of surfactants for wettability alteration in stimulation fluids and the potential for surfactant EOR in unconventional liquid reservoirs. In: SPE unconventional resources conference, April 1-3, The Woodlands, Texas, 2014. doi:10.2118/169001.

Anderson WG. Wettability literature survey-part 1: rock/oil/brine interactions and the effects of core handling on wettability. SPE J Pet Technol. 1986;10:1125-44. doi:10.2118/13932-PA.

Anderson WG. Wettability literature survey-part 4: effects of wettability on capillary pressure. J Pet Technol. 1987;39(10):1283-300. doi:10.2118/15271-PA.

Andrianov A, Farajzadeh R, Nick MM, et al. Immiscible foam for enhancing oil recovery: bulk and porous media experiments. Ind Eng Chem Res. 2012;51(5):2214-26. doi:10.1021/ie201872v.

Asl YA, Pope GA, Delshad M. Mechanistic modeling of chemical transport in naturally fractured oil reservoirs. In: SPE improved oil recovery symposium, Tulsa, Oklahoma, USA, 24-28 April 2010. doi:10.2118/129661-MS.

Azad MS, Sultan AS. Extending the applicability of chemical EOR in high salinity, high temperature \& fractured carbonate reservoir through viscoelastic surfactants. In: Saudi Arabia section technical symposium and exhibition, April 21-24, Al-Khobar, Saudi Arabia, 2010. doi:10.2118/172188-MS.

Bai B, Grigg RB. Kinetics and equilibria of calcium lignosulfonate adsorption and desorption onto limestone. In: SPE international symposium on oilfield chemistry, 2-4 February, The Woodlands, Texas, 2005. doi:10.2118/93098-MS.

Bai Y, Xiong C, Shang Z, et al. Experimental study on ethanolamine/surfactant flooding for enhanced oil recovery. Energy Fuels. 2014;28(3):1829-37. doi:10.1021/ef402313n.

Banat IM. Biosurfactants production and possible uses in microbial enhanced oil recovery and oil pollution remediation: a review. Biores Technol. 1995;51(1):1-12. doi:10.1016/09608524(94)00101-6.

Barakat Y, Fortney LN, Schechter RS, et al. Criteria for structuring surfactants to maximize solubilization of oil and water: II. Alkyl benzene sodium sulfonates. J Colloid Interface Sci. 1983;92(2):561-74. doi:10.1016/0021-9797(83)90177-7.

Barnes JR, Groen K, On A, et al. Controlled hydrophobe branching to match surfactant to crude composition for chemical EOR. In: SPE improved oil recovery symposium, Tulsa, Oklahoma, USA, 14-18 April 2012. doi:10.2118/154084-MS.

Barnes JR, Smit J, Smit J, et al. Development of surfactants for chemical flooding at difficult reservoir conditions. In: SPE symposium on improved oil recovery, Tulsa, Oklahoma, USA, 20-23 April 2008. doi:10.2118/113313-MS.

Bataweel MA, Nasr-El-Din HA. Alternatives to minimize scale precipitation in carbonate cores caused by alkalis in ASP flooding in high salinity/high temperature applications. In: SPE European formation damage conference, June 7-10, Noordwijk, The Netherlands, 2011. doi:10.2118/143155-MS.

Bera A, Kissmathulla S, Ojha K, et al. Mechanistic study of wettability alteration of quartz surface induced by nonionic surfactants and interaction between crude oil and quartz in the presence of sodium chloride salt. Energy Fuels. 2012;26(6):3634-43. doi:10.1021/ef300472k.

Bera A, Mandal A. Microemulsions: a novel approach to enhanced oil recovery: a review. J Pet Explor Prod Technol. 2015;5(3):255-68. doi:10.1007/s13202-014-0139-5.

Bezemer C, Bauer KA. Prevention of carbonate scale deposition: a well-packing technique with controlled solubility phosphates. J Pet Technol. 1969;21(4):505-14. doi:10.2118/2176-PA. 
Blaker T, Celius HK, Lie T, et al. Foam for gas mobility control in the Snorre field: the FAWAG project. In: SPE annual technical conference and exhibition, October 3-6, Houston, Texas, 1999. doi: $10.2118 / 56478-M S$.

Blunt M, Fayers FJ, Orr FM. Carbon dioxide in enhanced oil recovery. Energy Convers Manag. 1993;34(9):1197-204. doi:10. 1016/0196-8904(93)90069-M.

Boud DC, Holbrook OC. Gas drive oil recovery process. US Patents: 2866507. 1958.

Bourbiaux B, Fourno A, Nguyen AL, et al. Experimental and numerical assessment of chemical EOR in oil-wet naturallyfractured reservoirs. In: SPE improved oil recovery symposium, Tulsa, Oklahoma, USA, 12-16 April 2014. doi:10.2118/169140MS.

BP. Statistical Review of World Energy 2015. http://www.bp.com/ content/dam/bp/pdf/energy-economics/statistical-review-2015/ bp-statistical-review-of-world-energy-2015-full-report.pdf.

Chen HL, Lucas LR, Nogaret LAD, et al. Laboratory monitoring of surfactant imbibition using computerized tomography. In: SPE international petroleum conference and exhibition in Mexico, Villahermosa, Mexico, 1-3 February 2000. doi:10.2118/59006MS.

Chen Y, Elhag AS, Poon BM, et al. Ethoxylated cationic surfactants for $\mathrm{CO}_{2} \mathrm{EOR}$ in high temperature, high salinity reservoirs. In: SPE improved oil recovery symposium, April 14-18, Tulsa, Oklahoma, 2012. doi:10.2118/154222-MS.

Chen Y, Elhag AS, Poon BM, et al. Switchable nonionic to cationic ethoxylated amine surfactants for $\mathrm{CO}_{2}$ enhanced oil recovery in high-temperature, high-salinity carbonate reservoirs. SPE J. 2014;19(2):249-59. doi:10.2118/154222-PA.

Cheng KH. Chemical consumption during alkaline flooding: a comparative evaluation. In: SPE enhanced oil recovery symposium, April 20-23, Tulsa, Oklahoma, 1986. doi:10.2118/14944MS.

Chilingar GV, Yen TF. Some notes on wettability and relative permeabilities of carbonate reservoir rocks, II. Energy Sources. 1983;7(1):67-75. doi:10.1080/00908318308908076.

Dantas TNC, Soares PJ, Neto AOW, et al. Implementing new microemulsion systems in wettability inversion and oil recovery from carbonate reservoirs. Energy Fuels. 2014;28(11):6749-59. doi:10.1021/ef501697x.

Delamaide E, Moreau P, Tabary R. New approach for offshore chemical enhanced oil recovery. In: Offshore technology conference, 4-7 May, Houston, Texas, USA, 2015. doi:10. 4043/25919-MS.

Doll TE. An update of the polymer-augmented alkaline flood at the Isenhour Unit, Sublette County, Wyoming. SPE Reserv Eng. 1988;3(2):604-8. doi:10.2118/14954-PA.

Dong M, Liu Q, Li A. Displacement mechanisms of enhanced heavy oil recovery by alkaline flooding in a micromodel. Particuology. 2012;10(3):298-305. doi:10.1016/j.partic.2011.09.008.

Elhag AS, Chen Y, Reddy PP, et al. Switchable diamine surfactants for $\mathrm{CO}_{2}$ mobility control in enhanced oil recovery and sequestration. Energy Proc. 2014a;63:7709-16. doi:10.1016/j.ejypro. 2014.11.804.

Elhag AS, Chen Y, Chen H, et al. Switchable amine surfactants for stable $\mathrm{CO}_{2}$ /brine foams in high temperature, high salinity reservoirs. In: SPE improved oil recovery Symposium, April 12-16, Tulsa, Oklahoma, 2014b. doi:10.2128/169041-MS.

Elsharkawy AM, Alikhan AA. Models for predicting the viscosity of Middle East crude oils. Fuel. 1999;78(8):891-903. doi:10.1016/ S0016-2361(99)00019-8.

Embry A, Klovan JE. A late Devonian reef tract on northeastern Banks Island, N.W.T. Bull Can Pet Geol. 1971;19(4):730-81.

Enick RM, Olsen DK, Ammer JR. Mobility and conformance control for $\mathrm{CO}_{2} \mathrm{EOR}$ via thickeners, foams, and gels-a literature review of 40 years of research and pilot tests. In: SPE improved oil recovery symposium, April 14-16, Tulsa, Oklahoma, 2012. doi:10.2118/154122-MS.

Falls AH, Thigpen DR, Nelson RC, et al. Field test of cosurfactantenhanced alkaline flooding. SPE Reserv Eng. 1994;9(3):217-23. doi:10.2118/24117-PA.

Farajzadeh R, Andrianov A, Zitha PLJ. Investigation of immiscible and miscible foam for enhancing oil recovery. Ind Eng Chem Res. 2010;49(4):1910-9. doi:10.1021/ie901109d.

Farajzadeh R, Andrianov A, Krastev R, et al. Foam-oil interaction in porous media: implications for foam assisted enhanced oil recovery. Adv Coll Interface Sci. 2012;183-184:1-13. doi:10. 1016/j.cis.2012.07.002.

Gao P, Towler B. Investigation of polymer and surfactant-polymer injections in South Slattery Minnelusa reservoir, Wyoming. J Pet Explor Prod Technol. 2011;1(1):23-31. doi:10.1007/s13202010-0002-2.

Ge J, Feng A, Zhang G, et al. Study of the factors influencing alkaline flooding in heavy-oil reservoirs. Energy Fuels. 2012;26(5):2875-82. doi:10.1021/ef3000906.

Ghojavand H, Vahabzadeh F, Shahraki AK. Enhanced oil recovery from low permeability dolomite cores using biosurfactant produced by a bacillus mojavensis (PTCC 1696) isolated from Masjed-I Soleyman field. J Pet Sci Eng. 2012;81:24-30. doi:10. 1016/j.petrol.2011.12.002.

Glover CJ, Puerto MC, Maerker JM, et al. Surfactant phase behavior and retention in porous media. SPE J. 1979;19(3):183-93. doi:10.2118/7053-PA.

Guo H, Zitha PLJ, Faber R, et al. A novel alkaline/surfactant/foam enhanced oil recovery process. SPE J. 2012;17(4):1186-95. doi:10.2118/145043-PA.

Gupta R, Mohanty K. Temperature effects on surfactant-aided imbibition into fractured carbonates. SPE J. 2010;15(03):587-97. doi:10.2118/110204-PA.

Gupta R, Mohanty KK. Wettability alteration mechanism for oil recovery from fractured carbonate rocks. Transp Porous Media. 2011;87(2):635-52. doi:10.1007/s11242-010-9706-5.

Hanssen JE, Holt T, Surguchev LM. Foam processes: an assessment of their potential in North Sea reservoirs based on a critical evaluation of current field experience. In: SPE/DOE improved oil recovery symposium, April 17-20, Tulsa, Oklahoma, 1994. doi:10.2118/27768-MS.

He K, Yue Z, Fan C, et al. Minimizing surfactant adsorption using polyelectrolyte based sacrificial agent: a way to optimize surfactant performance in unconventional formations. In: SPE international symposium on oilfield chemistry, 13-15 April, The Woodlands, Texas, USA, 2015. doi:10.2118/173750-MS.

Hill HJ, Reisberg J, Stegemeier GL. Aqueous surfactant systems for oil recovery. J Pet Technol. 1973;25(2):186-94. doi:10.2118/ 3798-PA.

Hiorth A, Cathles LM, Madland MV. The impact of pore water chemistry on carbonate surface charge and oil wettability. Transp Porous Media. 2010;85(1):1-21. doi:10.1007/s11242010-9543-6.

Hirasaki G, Zhang DL. Surface chemistry of oil recovery from fractured, oil-wet, carbonate formations. In: International symposium on oilfield chemistry, Houston, Texas, 5-7 February 2003. doi:10.2118/80988-MS.

Hirasaki G, Miller CA, Puerto M. Recent advances in surfactant EOR. In: SPE annual technical conference and exhibition, Denver, Colorado, USA, 21-24 September 2008. doi:10.2118/115386-MS.

Hirasaki GJ, Domselaar HRV, Nelson RC. Evaluation of the salinity gradient concept in surfactant flooding. SPE J. 1983;23(3):486-500. doi:10.2118/8825-PA.

Hognesen EJ, Strand S, Austad T. Waterflooding of preferential oilwet carbonates: oil recovery related to reservoir temperature and 
brine composition. In: SPE Europec/EAGE annual conference, Madrid, Spain, 13-16 June 2005. doi:10.2118/94166-MS.

Hognesen EJ, Olsen M, Austad T. Capillary and gravity dominated flow regimes in displacement of oil from an oil-wet chalk using cationic surfactant. Energy Fuels. 2006;20(3):1118-22. doi:10. 1021/ef050297s.

Howard A. Recovery of petroleum from oil-bearing sands. 1927, US Patent: 1651311.

Huh C, Rossen WR. Approximate pore-level model for apparent viscosity of polymer-enhanced foam in porous media. SPE J. 2008;13(1):17-25. doi:10.2118/99653-PA.

Hussain A, Luckham PF, Tadros TF. Phase behaviour of $\mathrm{pH}-$ dependent microemulsions at high temperature and salinities. Rev Inst Fr Pét. 1997;52(2):228-31. doi:10.2516/ogst:1997024.

Jennings HY, Jognson CE, McAuliffe CD. A caustic waterflooding process for heavy oils. J Pet Technol. 1974;26(12):1344-52. doi:10.2118/4741-PA.

Johnson CE Jr. Status of caustic and emulsion methods. J Pet Technol. 1976;28(1):85-92. doi:10.2118/5561-PA.

Jones SA, Bent V, Farajzadeh R, et al. Surfactant screening for foam EOR: correlation between bulk and core-flood experiments. Colloids Surf A. 2016;500:166-76. doi:10.1016/j.colsurfa.2016. 03.072 .

Joshi $\mathrm{S}$, Bharucha $\mathrm{C}$, Jha $\mathrm{S}$, et al. Biosurfactant production using molasses and whey under thermophilic conditions. Biores Technol. 2008;99(1):195-9. doi:10.1016/j.biortech.2006.12.010.

Julio SSD, Emanuel AS. Laboratory study of foaming surfactant for $\mathrm{CO}_{2}$ mobility control. SPE Reserv Eng J. 1989;4(2):136-42. doi:10.2118/16373-PA.

Kang W, Xu B, Wang Y, et al. Stability mechanism of W/O crude oil emulsion stabilized by polymer and surfactant. Colloids Surf A. 2011;384(1-3):555-60. doi:10.1016/j.colsurfa.2011.05.017.

Kayali IH, Liu S, Miller CA. Microemulsions containing mixtures of propoxylated sulfates with slightly branched hydrocarbon chains and cationic surfactants with short hydrophobes or PO chains. Colloids Surf A. 2010;354(1-3):246-51. doi:10.1016/j.colsurfa. 2009.07.058.

Kiani M, Kazemi H, Ozkan E, et al. Pilot testing issues of chemical EOR in large fractured carbonate reservoirs. In: SPE annual technical conference and exhibition, Denver, Colorado, USA, 30 October-2 November 2011. doi:10.2118/146840-MS.

Kumar T, Vishwanatham S, Kundu SS. A laboratory study on pteroylL-glutamic acid as a scale prevention inhibitor of calcium carbonate in aqueous solution of synthetic produced water. J Pet Sci Eng. 2010;71(1-2):1-7. doi:10.1016/j.petrol.2009.11.014.

Lake LW. Enhanced oil recovery. Englewod Cliffs: Prentice-Hall Inc.; 1989.

Lawson JB. The adsorption of non-ionic and anionic surfactants on sandstone and carbonate. In: SPE symposium on improved methods of oil recovery, April 16-17, Tulsa, Oklahoma, 1978. doi:10.2118/7052-MS.

Le VQ, Nguyen Q, Sanders A. A novel foam concept with $\mathrm{CO}_{2}$ dissolved surfactants. In: SPE symposium on improved oil recovery, April 20-23, Tulsa, Oklahoma, 2008. doi:10.2118/ 113370-MS

Lee HO, Heller JP, Hoefer AMW. Change in apparent viscosity of $\mathrm{CO}_{2}$ foam with rock permeability. SPE Reserv Eng J. 1991;6(4):421-8. doi:10.2118/20194-PA.

Lefebvre C, Lemouzy P, Sorin D, et al. Building a roadmap for enhanced oil recovery prefeasibility study. In: SPE Russian oil and gas exploration and production technical conference and exhibition, 16-18 October, Moscow, Russia, 2012. doi:10.2118/ 159264-MS

Leonard J. Annual production report. Enhanced oil recovery. Oil Gas J. 1984;82(14):100-1.
Leonard J. Production/enhanced oil recovery report. Oil Gas J. 1986;84(15):94-5.

Levitt D, Jackson A, Britton LN, et al. Identification and evaluation of high-performance EOR surfactants. In: SPE/DOE symposium on improved oil recovery, April 22-26, Tulsa, Oklahoma, 2006. doi:10.2118/100089-MS.

Li D, Shi M, Wang D, et al. Chromatographic separation of chemicals in alkaline surfactant polymer flooding in reservoir rocks in the Daqing oil field. In: SPE international symposium on oilfield chemistry, April 20-22, The Woodlands, Texas, 2009. doi:10. 2118/121598-MS

Li RF, Yan W, Liu S, et al. Foam mobility control for surfactant enhanced oil recovery. SPE J. 2010;15(4):92842. doi:10.2118/ 113910-PA.

Liu S, Zhang D, Yan W, et al. Favorable attributes of alkalinesurfactant-polymer flooding. SPE J. 2008;13(1):5-16. doi:10. 2118/99744-PA.

Lu J, Liyanage PJ, Solairaj S, et al. New surfactant developments for chemical enhanced oil recovery. J Pet Sci Eng. 2014a;120:94-101. doi:10.1016/j.petrol.2014.05.021.

Lu J, Goudarzi A, Chen P, et al. Enhanced oil recovery from hightemperature, high-salinity naturally fractured carbonate reservoirs by surfactant flood. J Pet Sci Eng. 2014b;124:122-31. doi:10.1016/j.petrol.2014.10.016.

Lucia FJ. Carbonate reservoir characterization: an integrated approach. 2nd ed. Berlin: Springer; 2007. doi:10.1007/978-3540-72742-2.

Lv W, Bazin B, Liu Q, et al. Static and dynamic adsorption of anionic and amphoteric surfactants with and without the presence of alkali. J Pet Sci Eng. 2011;77(2):209-18. doi:10.1016/j.petrol. 2011.03.006.

Ma K, Cui L, Wang T, et al. Adsorption of cationic and anionic surfactants on natural and synthetic carbonate materials. J Colloid Interface Sci. 2013;408:164-72. doi:10.1016/j.jcis.2013.07.006.

Mackay EJ, Jordan MM, Feasey ND, et al. Integrated risk analysis for scale management in deepwater developments. SPE Prod Facil. 2005;20(2):138-54. doi:10.2118/7459-PA.

Mackay EJ, Jordan MM. Impact of brine flow and mixing in the reservoir on scale control risk assessment and subsurface treatment options: case histories. J Energy Res Technol. 2005;127(3):201-13. doi:10.1115/1.1944029.

Manrique EJ, Muci VE, Gurfinkel ME. EOR field experiences in carbonate reservoirs in the United States. SPE Reserv Eval Eng. 2007;10(6):667-86. doi:10.2118/100063-PA.

Masalmeh SK, Wei L, Blom C, Jing $X$ et al. EOR options for heterogeneous carbonate reservoirs currently under waterflooding. In: Abu Dhabi international petroleum exhibition and conference, Abu Dhabi, UAE, 10-13 November 2014. doi:10. 2118/171900-MS.

Mathiassen $\mathrm{OM} . \mathrm{CO}_{2}$ as injection gas for enhanced oil recovery and estimation of the potential on the Norwegian Continental Shelf. Ph.D. thesis. Dept. Pet. Eng. and Applied Geophysics, Norwegian University of Science and Technology, Trondheim, 2003.

Mayer EH, Berg RL, Weinbrandt RM. Alkaline injection for enhanced oil recovery - a status report. J Pet Technol. 1983;35(1):209-21. doi:10.2118/8848-PA.

McCafferty JF, McClafin GG. The field application of a surfactant for the production of heavy, viscous crude oils. In: SPE annual technical conference and exhibition, Washington, DC, 4-7 October 1992. doi: 10.2118/24850-MS.

McLendon WJ, Koronaios P, Enick RM, et al. Assessment of $\mathrm{CO}_{2^{-}}$ soluble non-ionic surfactants for mobility reduction using mobility measurements and CT imaging. J Pet Sci Eng. 2014;119:196-209. doi:10.1016/j.petrol.2014.05.010.

Mohammed M, Babadagli T. Alteration of matrix wettability during alternate injection of hot-water/solvent into heavy-oil containing 
fractured reservoirs. In: SPE heavy oil conference-Canada, Calgary, Alberta, Canada, 10-12 June 2014. doi:10.2118/ 170034-MS

Morrow NR, Mason G. Recovery of oil by spontaneous imbibition. Curr Opin Colloid Interface Sci. 2001;6(4):321-37. doi:10.1016/ S1359-0294(01)00100-5.

Niu Y, Jian O, Zhu Z, et al. Research on hydrophobically associating water-soluble polymer used for EOR. In: SPE international symposium on oilfield chemistry, February 13-16, Houston, Texas, 2001. doi:10.2523/65378-MS.

Olajire AA. Review of ASP EOR (alkaline surfactant polymer enhanced oil recovery) technology in the petroleum industry: prospects and challenges. Energy. 2014;77:963-82. doi:10.1016/ j.energy.2014.09.005.

Olsen DK, Hicks MD, Hurd BG, et al. Design of a novel flooding system for an oil-wet central Texas carbonate reservoir. In: SPE/ DOE enhanced oil recovery symposium, April 22-25, Tulsa, Oklahoma, 1990. doi:10.2118/20224-MS.

Oscar M, Portilla-Rivera SJT-L, Jose AR, et al. Production of microbial transglutaminase on media made from sugar cane molasses and glycerol. Food Technol Biotechnol. 2007;47(1):19-26.

Pattarino F, Marengo E, Trotta M, et al. Combined use of lecithin and decvl polyglucoside in microemulsions: domain of existence and cosurfactant effect. J Dispers Sci Technol. 2000;21(3):345-63. doi:10.1080/01932690008913271.

Pei H, Zhang G, Ge J, et al. Analysis of microscopic displacement mechanisms of alkaline flooding for enhanced heavy-oil recovery. Energy Fuels. 2011;25(10):4423-9. doi:10.1021/ef200605a.

Pons-Jimenez M, Cartas-Rosado R, Martinez-Magadan JM, et al. Theoretical and experimental insights on the true impact of $\mathrm{C}_{12}$ TAC cationic surfactant in enhanced oil recovery for heavy oil carbonate reservoirs. Colloids Surf A. 2014;455:76-91. doi:10.1016/j.colsurfa.2014.04.051.

Quadri SMR, Jiran L, Shoaib M, et al. Application of biopolymer to improve oil recovery in high temperature high salinity carbonate reservoirs. In: Abu Dhabi international petroleum exhibition and conference, November 9-12, Abu Dhabi, UAE, 2015. doi:10. 2118/177915-MS

Ren $\mathrm{G}$, Zhang $\mathrm{H}$, Nguyen QP. Effect of surfactant partitioning between $\mathrm{CO}_{2}$ and water on $\mathrm{CO}_{2}$ mobility control in hydrocarbon reservoirs. In: SPE enhanced oil recovery conference, July 19-2, Kuala Lumpur, Malaysia, 2011. doi:10.2118/145102-MS.

Rilian NA, Sumestry M, Wahyuningish W. Surfactant stimulation to increase reserves in carbonate reservoir: "a case study in Semoga field". In: SPE EUROPEC/EAGE annual conference and exhibition, June 14-17, Barcelona, Spain, 2008. doi:10. 2118/130060-MS

Rogers JD, Grigg RB. A literature analysis of the WAG injectivity abnormalities in the $\mathrm{CO}_{2}$ process. SPE Reserv Eval Eng. 2001;4(5):375-86. doi:10.2118/73830-PA.

Rosen $\mathrm{MJ}$, Li F. The adsorption of gemini and conventional surfactants onto some soil solids and the removal of 2-naphthol by the soil surfaces. J Colloid Interface Sci. 2001;234(2):418-24. doi:10.1006/jcis.2000.7293

Rosen MJ, Kunjappu JT. Surfactants and interfacial phenomena. 4th ed. Hoboken: Wiley; 2012.

Sagi AR, Puerto MC, Bian Y, et al.Laboratory studies for surfactant flood in low-temperature, low-salinity fractured carbonate reservoir. In: SPE international symposium on oilfield chemistry, April 8-10, The Woodlands, Texas, 2013. doi:10.2118/164062MS.

Sagir M, Tan IM, Mushtaq M, et al. Synthesis of a new $\mathrm{CO}_{2}$ philic surfactant for enhanced oil recovery applications. J Dispers Sci Technol. 2013;35(5):647-54. doi:10.1080/01932691.2013. 803253.
Sahni V, Dean RM, Britton C, et al. The role of co-solvents and cosurfactants in making chemical floods robust. In: SPE improved oil recovery symposium, Tulsa, Oklahoma, USA, 24-28 April 2010. doi:10.2118/130007-MS.

Salager JL, Anton R, Sabatini D, et al. Enhancing solubilization in microemulsions - state of the art and current trends. J Surfactants Deterg. 2005;8(1):3-21. doi:10.1007/s11743-005-0328-4.

Saleh M, Johnson SJ, Liang JT. Mechanistic study of wettability alteration using surfactants with applications in naturally fractured reservoirs. Langmuir. 2008;24(24):14099-107. doi:10. 1021/la802464u.

Santvoort JFM, Golombok M. Viscoelastic surfactants for diversion control in oil recovery. J Pet Sci Eng. 2015;135:671-7. doi:10. 1016/j.petrol.2015.10.030.

Sarafzadeh P, Niazi A, Oboodi V, et al. Investigating the efficiency of MEOR processes using Enterobacter cloacae and Bacillus stearothermophilus SUCPM\#14 (biosurfactant-producing strains) in carbonated reservoirs. $J$ Pet Sci Eng. 2014;113:46-53. doi:10.1016/j.petrol.2013.11.029.

Schramm LL, Wassmuth F. Foams: basic principles. Chapter 1. In: Schramm LL, editor. Foams: fundamentals and applications in the petroleum industry. Washington, DC: American Chemical Society; 1994. p. 3-45. doi:10.1021/ba-1994-0242.ch001.

Schwuger MJ, Stickdorn K, Schomaecker R. Microemulsions in technical processes. Chem Rev. 1995;95(4):849-64. doi:10. 1021/cr00036a003.

Seethepalli A, Adibhatla B, Mohanty KK. Physicochemical interactions during surfactant flooding of fractured carbonate reservoirs. SPE J. 2004;9(4):411-8. doi:10.2118/89423-PA.

Shah DO. Symposium on surface phenomena in enhanced oil recovery, surface phenomena in enhanced oil recovery, vol. xii. New York: Plenum Press; 1981. p. 874.

Shahri MP, Shadizadeh SR, Jamialahmadi M. A new type of surfactant for enhanced oil recovery. Pet Sci Technol. 2012;30(6):585-93. doi:10.1080/10916466.2010.489093.

ShamsiJazeyi H, Verduzco R, Hirasaki GJ. Reducing adsorption of anionic surfactant for enhanced oil recovery: part I. Competitive adsorption mechanism. Colloids Surf A. 2014a;453:162-7. doi:10.1016/j.colsurfa.2013.10.042.

ShamsiJazeyi H, Verduzco R, Hirasaki GJ. Reducing adsorption of anionic surfactant for enhanced oil recovery: part II. Applied aspects. Colloids Surf A. 2014b;453:168-75. doi:10.1016/j. colsurfa.2014.02.021.

Sharma G, Mohanty KK. Wettability alteration in high temperature and high salinity carbonate reservoirs. SPE J. 2013;18(4):646-55. doi:10.2118/147306-PA.

Shen P, Wang J, Yuan S, et al. Study of enhanced-oil-recovery mechanism of alkali/surfactant/polymer flooding in porous media from experiments. SPE J. 2009;14(2):237-44. doi:10. 2118/126128-PA.

Sheng JJ. Optimum phase type and optimum salinity profile in surfactant flooding. J Pet Sci Eng. 2010;75(1-2):143-53. doi:10. 1016/j.petrol.2010.11.005.

Sheng JJ. Modern chemical enhanced oil recovery. Boston: Gulf Professional Publishing; 2011.

Sheng JJ. Enhanced oil recovery field case studies. Boston: Gulf Professional Publishing; 2013. p. 143-67.

Sheng JJ. Status of surfactant EOR technology. Petroleum. 2015;1(2):97-105. doi:10.1016/j.petlm.2015.07.003.

Simjoo M, Dong Y, Andrianov A, et al. CT scan study of immiscible foam flow in porous media for enhancing oil recovery. Ind Eng Chem Res. 2013;52(18):6221-33. doi:10.1021/ie300603v.

Smith PG, Dhanuka VV, Hwang HS, et al. Tertiary amine esters for carbon dioxide based emulsions. Ind Eng Chem Res. 2007;46(8):2473-80. doi:10.1021/ie060934h. 
Somasundaran P, Hanna HS. Physico-chemical aspects of adsorption at solid/liquid interfaces. In: Shah DO, Schechter RS, editors. Improved oil recovery by surfactant and polymer flooding. New York: Academic Press; 1977. p. 205-51.

Somasundaran P, Zhang L. Adsorption of surfactants on minerals for wettability control in improved oil recovery processes. J Pet Sci Eng. 2006;52(1-4):198-212. doi:10.1016/j.petrol.2006.03.022.

Srivastava M, Zhang J, Nguyen QP, et al. A systematic study of alkali surfactant gas injection as an enhanced oil recovery technique. In: SPE annual technical conference and exhibition, October 4-7, New Orleans, Louisiana, 2009. doi:10.2118/124752-MS.

Srivastava M, Nguyen QP. Application of gas for mobility control in chemical EOR in problematic carbonate reservoirs. In: SPE improved oil recovery symposium, April 24-28, Tulsa, Oklahoma, 2010. doi:10.2118/129840-MS.

Standnes DC, Austad T. Wettability alteration in carbonates: interaction between cationic surfactant and carboxylates as a key factor in wettability alteration from oil-wet to water-wet conditions. Colloids Surf A. 2003;216(1-3):243-59. doi:10. 1016/S0927-7757(02)00580-0.

Standnes DC, Austad T. Wettability alteration in chalk: 1 . Preparation of core material and oil properties. J Pet Sci Eng. 2000a;28(3):111-21. doi:10.1016/S0920-4105(00)00083-8.

Standnes DC, Austad T. Wettability alteration in chalk: 2 . mechanism for wettability alteration from oil-wet to water-wet using surfactants. J Pet Sci Eng. 2000b;28(3):123-43. doi:10.1016/ S0920-4105(00)00084-X.

Stoll M, Al-Shreqi H, Finol J, et al. Alkaline-surfactant-polymer flood: From the laboratory to the field. In: SPE EOR conference at oil \& gas west Asia, April 11-13, Muscat, Oman, 2010. doi:10.2118/129164-MS.

Strand S, Standnes DC, Austad T. Spontaneous imbibition of aqueous surfactant solutions into neutral to oil-wet carbonate cores: effects of brine salinity and composition. Energy Fuels. 2003;17(5):1133-44. doi:10.1021/ef030051s.

Strand S, Hognesen EJ, Austad T. Wettability alteration of carbonates: effects of potential determining ions $\left(\mathrm{Ca}^{2+}\right.$ and $\left.\mathrm{SO}_{4}{ }^{2-}\right)$ and temperature. Colloids Surf A. 2006;275(1-3):1-10. doi:10.1016/ j.colsurfa.2005.10.061.

Sultan AS, Azad MS, Hussein IA, et al. Rheological assessment of VES as an EOR fluid in carbonate reservoir. In: SPE EOR conference at oil and gas west Asia, March 31-April 2, Muscat, Oman, 2014. doi:10.2118/169744-MS.

Symonds RWP, Ali SMF, Thomas S. A laboratory study of caustic flooding for two Alberta crude oils. J Can Pet Technol. 1991; doi:10.2118/91-01-02.

Tabary R, Douarche F, Bazin B, et al. Design of a surfactant/polymer process in a hard brine context: a case study applied to Bramberge Reservoir. In: SPE EOR conference at oil and gas West Asia, 16-18 April, Muscat, Oman, 2012. doi:10.2118/ 155106-MS.

Talebian SH, Masoudi R, Mohd I, et al. Foam assisted $\mathrm{CO}_{2}$-EOR: a review of concept, challenges, and future prospects. J Pet Sci Eng. 2014;120:202-15. doi:10.1016/j.petrol.2014.05.013.

Talebian SH, Tan IM, Sagir M, et al. Static and dynamic foam/oil interactions: potential of $\mathrm{CO}_{2}$-philic surfactants as mobility control agents. J Pet Sci Eng. 2015;135:118-26. doi:10.1016/j. petrol.2015.08.011.

Tay A, Oukhemanou F, Wartenberg N, et al. Adsorption inhibitors: a new route to mitigate adsorption in chemical enhanced oil recovery. In: SPE Asia Pacific enhanced oil recovery conference, 11-13 August, Kuala Lumpur, Malaysia, 2015. doi:10.2118/ 174603-MS.

Uren LC, Fahmy EH. Factors influencing the recovery of petroleum from unconsolidated sands by waterflooding. Trans AIME. 1927;77(1):318-35. doi:10.2118/927318-G.
Vargo J, Turner J, Vergnani B, et al. Alkaline-surfactant-polymer flooding of the Cambridge Minnelusa field. SPE Reserv Eval Eng. 2000;3(6):552-8. doi:10.2118/55633-MS.

Vdovic N, Biscan J. Electrokinetics of natural and synthetic calcite suspensions. Colloids Surf A Physicochem Eng Aspect. 1998;137(1):7-14. doi:10.1016/S0927-7757(97)00179-9.

Vijapurapu CS, Rao DN. Compositional effects of fluids on spreading, adhesion and wettability in porous media. Colloids Surf A. 2004;241(1-3):335-42. doi:10.1016/j.colsurfa.2004.04.024.

Vikingstad AK, Aarra MG. Comparing the static and dynamic foam properties of a fluorinated and an alpha olefin sulfonate surfactant. J Pet Sci Eng. 2009;65(1-2):105-11. doi:10.1016/j. petrol.2008.12.027.

Vikingstad AK, Skauge A, Hoiland H, et al. Foam-oil interactions analyzed by static foam tests. Colloids Surf A. 2005;260(1-3):189-98. doi:10.1016/j.colsurfa.2005.02.034.

Wang H, Cao X, Zhang A, et al. Development and application of dilute surfactant-polymer flooding system for Shengli Oilfield. J Pet Sci Eng. 2009;65(1-2):45-50. doi:10.1016/j.petrol.2008. 12.021.

Wang J, Han M, Fuseni AB, et al. Surfactant adsorption in surfactantpolymer flooding for carbonate reservoirs. In: SPE Middle East oil \& gas show and conference, March 8-11, Manama, Bahrain, 2015. doi:10.2118/172700-MS.

Wang L, Mohanty K. Enhanced oil recovery in gasflooded carbonate reservoirs by wettability-altering surfactants. In: SPE annual technical conference and exhibition, New Orleans, Louisiana, USA, 30 September-2 October 2013. doi: 10.2118/166283-MS.

Wang Y, Zhao F, Bai B. Optimized surfactant IFT and polymer viscosity for surfactant-polymer flooding in heterogeneous formations. In: SPE improved oil recovery symposium, Tulsa, Oklahoma, USA, 24-28 April 2010. doi:10.2118/127391-MS.

Webb KJ, Black CJJ, Tjetland G. A Laboratory study investigating methods for improving oil recovery in carbonates. In: International petroleum technology conference, Doha, Qatar, 21-23 November 2005. doi:10.2523/IPTC-10506-MS.

Weiss WW, Xie X, Weiss J, et al. Artificial intelligence used to evaluate 23 single-well surfactant-soak treatments. SPE Reserv Eval Eng. 2006;9(3):209-16. doi:10.2118/89457-PA.

Winsor A. Solvent properties of amphiphilic compounds. Butterworth Sci Publ. 1956;58(12):1103-4. doi:10.1002/ange.19560681521.

Wu Y, Shuler PJ, Blanco M, et al. An experimental study of wetting behavior and surfactant EOR in carbonates with model compounds. SPE J. 2008;13(1):26-34. doi:10.2118/99612-PA.

Xie X, Weiss WW, Tong ZJ, et al. Improved oil recovery from carbonate reservoirs by chemical stimulation. In: SPE/DOE symposium on improved oil recovery, Tulsa, Oklahoma, 17-21 April 2004. doi:10.2118/89424-PA.

$\mathrm{Xu}$ X, Saeedi A, Liu K. An experimental study of combined foam/surfactant polymer (SP) flooding for carbon dioxideenhanced oil recovery $\left(\mathrm{CO}_{2}\right.$-EOR $)$. J Pet Sci Eng. 2017;149:603-11. doi:10.1016/j.petrol.2016.11.022.

Yang HD, Wadleigh EE. Dilute surfactant IOR - design improvement for massive, fractured carbonate applications. In: SPE international petroleum conference and exhibition in Mexico, Villahermosa, Mexico, 1-3 February 2000. doi:10.2118/59009-MS.

Yin DY, Zhang XR. Evaluation and research on performance of a blend surfactant system of alkyl polyglycoside in carbonate reservoir. J Pet Sci Eng. 2013;111:153-8. doi:10.1016/j.petrol. 2013.08.032.

Youssef N, Simpson DR, Duncan KE, et al. In situ biosurfactant production by bacillus strains injected into a limestone petroleum reservoir. Appl Environ Microbiol. 2007;73(4):1239-47. doi:10.2238/AEM.02264-06.

Zahedzadeh M, Karambeigi MS, Emadi MA, et al. Comprehensive management of mineral scale deposition in carbonate oil fields- 
a case study. Chem Eng Res Des. 2014;92(11):2264-72. doi:10. 1016/j.cherd.2014.03.014.

Zendehboudi S, Ahmadi MA, Rajabzadeh AR, et al. Experimental study on adsorption of a new surfactant onto carbonate reservoir samples-application to EOR. Can J Chem Eng. 2013;91(8):1439-49. doi:10.1002/cjce.21806.

Zhang R, Somasundaran P. Advances in adsorption of surfactants and their mixtures at solid/solution interfaces. Adv Coll Interface Sci. 2006;123-126:213-29. doi:10.1016/j.cis.2006.07.004.

Zhou M, Rhue RD. Effect of interfacial alcohol concentrations on oil solubilization by sodium dodecyl sulfate micelles. J Colloid Interface Sci. 2000;228(1):18-23. doi:10.1006/jcis.2000.6924.

Zhu Y, Weng H, Chen Z, et al. Compositional modification of crude oil during oil recovery. J Pet Sci Eng. 2003;38(1-2):1-11. doi:10.1016/S0920-4105(03)00018-4.

Zhu Y, Xu G, Gong H, et al. Production of ultra-low interfacial tension between crude oil and mixed brine solution of Triton
X-100 and its oligomer Tyloxapol with cetyltrimethylammonium bromide induced by hydrolyzed polyacrylamide. Colloids Surf A. 2009;332(2-3):90-7. doi:10.1016/j.colsurfa.2008.09.012.

Zhu Y, Zhang Y, Niu J, et al. The research progress in the alkali-free surfactant-polymer combination flooding technique. Pet Explor Dev. 2012;39(3):371-6. doi:10.1016/S1876-3804(12)60053-6.

Zhu Y, Wang Z, Wu K, et al. Enhanced oil recovery by chemical flooding from the biostromal carbonate reservoir. In: SPE enhanced oil recovery conference, July 2-4, Kuala Lumpur, Malaysia, 2013. doi:10.2118/165208-MS.

Zubari HK, Sivakumar VCB. Single well tests to determine the efficiency of alkaline-surfactant injection in a highly oil-wet limestone reservoir. In: Middle East oil show, June 9-12, Bahrain, 2003. doi:10.2118/81464-MS. 